ANUARIO DE ESTUdios MEDIEVALES

45/2, julio-diciembre de 2015, pp. 677-713

ISSN 0066-5061

doi:10.3989/aem.2015.45.2.02

\title{
PANTEONES REGIOS LEONESES (924-1109). CONCATENACIONES DINÁSTICAS Y DISCONTINUIDADES TOPOGRÁFICAS
}

\author{
ROYAL PANTHEONS IN LEON (924-1109). \\ DYNASTIC CONCATENATIONS AND TOPOGRAPHICAL \\ DISCONTINUITIES
}

\author{
GERARDO BOTO VARELA \\ Universitat de Girona
}

Para Carlota y para Aina

\begin{abstract}
Resumen: Este examen histórico-artístico de los cementerios regios de León y Sahagún explora crónicas y edificios. Los análisis revelan diversidad de soluciones y actitudes. Por ello, deben cuestionarse los axiomas historiográficos de uniformidad de modelos, continuidad lineal y unicidad de una presunta tradición hispana. Ya que un motor del relato histórico es el linaje de los monarcas, se escruta la genealogía arquitectónica y funcional de los panteones constituidos por y para los reyes de León, atendiendo a los vínculos, sucesiones y discontinuidades. Desvelar algunas penumbras de los sepulcros de los soberanos ayuda a comprender dónde radica el encadenamiento y la subsistencia del reino mismo.
\end{abstract}

Palabras clave: panteones regios; reino de León; Palat de Rey; San Isidoro de León; Sahagún.

\begin{abstract}
This article examines the royal cemeteries in Leon and Sahagún from an art-historical perspective. This topic demands analysing the documents as well as the architectonic settings. In the royal chronicles, the thread of historical narrative is the lineage of kings. For that reason, I discuss here the architectural and functional genealogy of the graveyards for the kings of Leon. This analysis explores both the links and the oppositions between these cemeteries. Studying the graves and cemeteries of the Kings facilitates understanding what order maintained the kingdom itself.
\end{abstract}

Keywords: kingdom of Leon; royal tombs; Palat de Rey; San Isidoro de Leon; Sahagún.

\section{SUMARIO}

1. Introducción.- 2. Precedentes: Santa María de Oviedo.- 3. Primeros panteones leoneses: la catedral de Santa María y Palat de Rey.- 4. La conciencia dinástica y el nuevo panteón de San Juan Bautista.- 5. Palacios y panteones.- 6. Apertura y clausura de los cementerios dinásticos: San Isidoro y Sahagún.- 7. Conclusión.8. Bibliografía citada. 


\section{INTRODUCCIÓN}

La historiografía artística viene afirmando que el panteón regio de Oviedo y sus homólogos de León, especialmente el organizado a occidente de San Juan Bautista (San Isidoro), mantuvieron similitudes topográficas y morfológicas. Presuntamente, se expresarían así los vínculos genealógicos y tipológicos de esos cementerios. La formulación de esta hipótesis considera algunos rasgos pero desdeña otros. El examen pormenorizado de la progenie arquitectónica y funcional de los panteones de los primeros reyes de León permite advertir las disparidades formales, funcionales y organizativas que mediaron entre ellos. Por ende, cabrá desmentir la tipificación de un paradigma único de panteón regio hispano, y ni siquiera asturleonés. La tradicional propuesta interpretativa que aboga por reconocer la vigencia de una fórmula cementerial subraya -y se contextualiza en- una perspectiva más amplia, la del mito de la continuidad histórica ${ }^{1}$, argumento de intenso debate en la historiografía hispana. Este escrutinio material y documental de los sucesivos cementerios leoneses no sólo intenta explicar qué factores y agentes propiciaron los respectivos traslados, sino dónde radicaron sus disparidades rituales y espaciales, sus vínculos históricos y sus innovaciones. Así, cabe reconsiderar la tesis de que en el siglo IX se generase un modelo de cementerio regio vigente en los tres siglos siguientes. Visto con detenimiento, se colige que el paisaje cementerial resultó ser plural y dispar. Así pues, no cabe seguir arguyendo una mecánica continuidad monumental.

\section{PRECEDENTES: SANTA MARÍA DE OVIEDO}

De acuerdo con todos los indicios, fue el propio Alfonso II quien decidió ser inhumado en el atrio de San Salvador. Que solicitara tumba en el seno de la iglesia de Santa María me parece probable, pero no indudable. Acaso él mismo mandó añadir en el extremo occidental de esa iglesia una habitación que sirviera de receptáculo funerario. Cuando menos, la crónica de Alfonso III, versión ad Sebastianum, le atribuye la obra: etiam in occidentali parte huius venerande domus edem ad recondenda regum adstruxit corpora ${ }^{2}$.

\footnotetext{
${ }^{1}$ Agradezco a Patrick Henriet su generosidad y magisterio al leer críticamente este trabajo, enmarcado en el proyecto URV-Banco Santander, ref. 2012LINE-05, dirigido por la Dra. Marta Serrano.

Sobre la idea de continuidad: Mattoso 1993, pp. 79-95. Menjot 1998, pp. 127-138.

${ }^{2}$ Gil, Moralejo, Ruiz de la Peña 1985, pp. 139 y 213-215. En la traducción se propone "construyó", pero el verbo adstruo sugiere más bien añadir o contribuir. Esta diferencia semántica es básica porque la primera acepción no sugiere un orden temporal, mientras que añadidura 
Si el recinto existía ya, quedaría inaugurado funcionalmente con el sepulcro del Casto (842). Se trataba de una habitación funeraria, adherida a un templo precedente, como lo explicita el verbo empleado por la fuente y constataron las exploraciones arqueológicas de 1926. El muro de la estancia acometía contra el preexistente estucado y las molduras de las pilastras del paramento oeste de Santa María ${ }^{3}$

La iglesia de Santa María fue incentivada por Alfonso II en el marco de su proyecto global ovetense. No obstante, el templo y su mausoleo se realizaron de modo sucesivo, no simultáneo ${ }^{4}$. Así, la vocación originaria de Santa María no fue contener un panteón dinástico estructuralmente definido ${ }^{5}$, aunque pudo ser el mismo monarca quien lo requirió ${ }^{6}$.

No hay certezas para reconocer la existencia de un panteón generacional en Asturias antes del reinado de Alfonso II. Acaso, y con severas objeciones documentales y arqueológicas ${ }^{7}$, pudiera haberlo sido Santianes de Pravia, presunto escenario de las tumbas del princeps Silo $(\uparrow 783)$, Adosinda y el rey Mauregato $(\uparrow 789)^{8}$. Con todo, aunque la iglesia praviana hubiera asumido

o contribución sí lo implica. Según Martínez 2004, T. I, p. 236, n. 1103, T. I, p. 377 y T. III, p. 398 la terminología de los siglos VI y X discierne "dos tipos de actuaciones constructivas constatadas: las emprendidas a partir de un edificio preexistente -y encaminadas a restaurar(retaurare, resurgire), a reparar a semejanza de cómo era inicialmente (instaurare), a ampliar (dilatare, adicere, adstruere, ampliare), a ampliar desde los cimientos (a fundamenti) y las realizadas ex novo".

${ }^{3}$ García de Castro 1995, pp. 398-405; 1999, pp. 30 y ss. En su estela, Alonso 2005, n. 11 sugiere que, en todo caso, existía en tiempos de Ordoño I. Además, Martínez 1993b, pp. 149161; 1993a, pp. 178 y ss. La solución de la tribuna regia encima del cubículo cementerial fue propuesta por Francisco de Selgas a partir de las descripciones de Morales, Carballo y Tirso de Avilés. Las dimensiones y la primera reflexión historiográfica sobre el recinto en Selgas 1890 , p. 294. Para Schlunk 1980, p. 145 el cubículo funerario fue añadido, cerrando intercolumnios entre dos pilares inicialmente exentos. García de Castro 1997, pp. 159-170.

${ }^{4}$ Bango 1992a, pp. 100-101; Martínez 1993b, p 156; 1993a, pp. 178 y ss. Analiza el conjunto García de Castro 1995, pp. 395-405; 1999, pp. 21-73; Carrero 2003, pp. 29-78.

${ }^{5}$ Recondo significa ocultar, preservar, pero también recolocar o reinstalar. Alfonso II no pudo recolocar cuerpos. Los de sus predecesores, presuntamente, se encontraban en Cangas, en valle Lagneio o en Pravia y nada hizo por trasladarlos. Interpreto que Alfonso II -si no, sus sucesores- pretendía depositar y proteger los cuerpos de futuros reyes. Al mismo término recondo recurre la Crónica para describir la reserva de reliquias apostólicas en los altares de San Salvador. Enunciar monarcas, en plural, sólo puede efectuarse desde la perspectiva de los cronistas de Alfonso III, que ya constatan los cuerpos de Alfonso II, Ramiro I y Ordoño I en aquel lugar. Así, ad recondenda sería una proposición ad futurum y no una acción retrospectiva.

${ }^{6}$ La inscripción del túmulo, transcrita por el Albendense, la acepta como válida, Diego, 1994, pp. 68-70.

${ }^{7}$ Alonso 2008, p. 45. No se hallaron tumbas en el problemático nártex. Las dos, de cronología incierta, exhumadas en el transepto sur cuestionarían la prescripción del I Concilio de Braga (561) si fueran anteriores al siglo XII. López, Martínez 2009, pp. 153-184.

${ }^{8}$ Discutió los testimonios de los cronistas modernos, Selgas 1890, p. 301; 1902, pp. 5-14. Menéndez Pidal 1980, p. 293 señala la existencia de dos tumbas conspicuas en el transepto sur, sin detallar prelación temporal. Fernández, Santos 1987, pp. 315-344. Fernández, Alonso, 
tal finalidad no se puede demostrar que se erigió con ese explícito propósito, ni siquiera su pórtico -análogo al de San Juan de Baños-. De hecho, sólo los cronistas modernos aseguran su presencia en este espacio transitorio. No hay modo de aseverar si Mauregato, Adosinda y Silo descansaron en un sepulcro inhumado o no, en el exterior, dentro del vestíbulo o en la iglesia9 ${ }^{9}$.

El cambio cualitativo que introduce el habitáculo cementerial de Santa María de Oviedo en el panorama monumental astur -y aun hispano- radica en su disposición en el interior del templo. Selgas razonó que esa inédita disposición topográfica vino inspirada por los contactos de la corte de Alfonso II con el mundo carolingio ${ }^{10}$, quizá atendiendo a precedentes como el traslado del cuerpo de Pipino el Breve desde los limite basilice de Saint-Denis al interior del contraábside por voluntad de Carlomagno. No obstante, este paralelo es cuestionable porque no se justifica por qué los recintos funerarios franco-germánicos eran transitables ya en el siglo IX y el ovetense, en cambio, imposibilitó el paso entre las tumbas.

No fue Alfonso II quien decidió que la domus de Santa María se consumara como panteón plural. Él no aglutinó cadáveres de predecesores ${ }^{11}$. Fue Ramiro I $(† 850)$ o quizá Ordoño I $(† 866)$ quien advirtió que a través del acotado cementerio podía explicitarse la conciencia de continuidad histórica y política, ya que no familiar ${ }^{12}$. Padre e hijo asumieron un cementerio precedente como una óptima estrategia de legitimización. Los gobernantes anteriores no desarrollaron esa elucubración porque la monarquía astur fue codificada y consolidada sólo por Alfonso II y porque con anterioridad no hubo un dispositivo monumental $a d h^{13} c^{13}$. En suma, Alfonso II dispuso un cementerio para sí y todo lo más propuso un panteón para sus sucesores, pero en modo alguno invocó vínculos pretéritos ${ }^{14}$. Su propuesta, novedosa en el solar ibérico, atrajo incluso al primer rey que fijó su civitas regia en León, García I

Argüello 1991, pp. 11-38. Las excavaciones no pudieron probar enterramientos en el pórtico occidental.

${ }^{9}$ Alonso 2005, p. 371 recela de la espuria referencia de que Cindasvintus fuera enterrado "intus ecclesiam", noticia insólita en un mundo visigodo ganado por el mutismo.

${ }^{10}$ Selgas 1890, p. 299.

${ }^{11}$ Así tiene que interpretarse la lectura de Selgas 1902,pp. 68-88.

${ }^{12}$ En sendos documentos de 857 Ordoño I y de 905 Alfonso III se autoproclaman el "tercero y cuarto en la sucesión del rey Casto”. España Sagrada, T. XXXVII, Ap., X y XI, 323 y 329. Debo al Dr. Martínez Tejera esta indicación.

${ }^{13}$ Ruiz de la Peña 2001.

${ }^{14} \mathrm{Su}$ teórico neovisigotismo fue una proyección retrospectiva aplicada por los cronistas de Alfonso III, -él sí- neovisigotista vocacional. Bango 1992b, pp. 19-32 ve en el conjunto ovetense una expresión de continuismo godo. La trama ideológica en Deswarte 2003. 
$(\dagger 914)^{15}$; con posterioridad, se instaló también en Oviedo el cuerpo de Alfonso $\mathrm{III}^{16}$, inhumado en primera instancia en Astorga ${ }^{17}$.

\section{PRIMEROS PANTEONES LEONESES: LA CATEDRAL DE SANTA MARÍA Y PALAT DE REY}

Ordoño II enraizó sus fundamentos políticos y su panteón personal en León; otra opción ya no tenía sentido. Gobernó desde el edificio de las viejas termas romanas y cedió algunas de aquellas salas para instalar la sede catedralicia ${ }^{18}$, allí fue inhumado. En su momento supuse que el lugar de inhumación pudo haber sido análogo a la habitación cementerial de Oviedo y no se me ocurre otra alternativa más estimable ${ }^{19}$, dado que el monarca pudo intervenir a su antojo en la configuración topográfica del conjunto catedrali$\mathrm{cio}^{20}$. Explícito, Sampiro señaló que sepultus fuit in aula sancte Marie semper viriginis sedis Legionensis ${ }^{21}(\dagger 924)$. ¿Quiere esto decir que se depositó -como en Oviedo- dentro de ella? Imposible aseverarlo. Su panteón, donde quiera que estuviera, acogió a su hermano Fruela II al año siguiente (†925), quien sepultus iusta fratrem suum legioni fuit, según el obispo Pelayo, tomando la voz de Sampiro ${ }^{22}$.

\footnotetext{
${ }^{15}$ Pérez de Urbel 1952, p. 309: García I "morbo propio discessit, et Oueto, cum aliis regibus, sepultus fuit" interpoló el obispo Pelayo. Sampiro fue el primer cronista que detalla el lugar ocupado por las tumbas regias, aunque Pelayo incrementó buena parte de esas informaciones (véase n. 46 infra). Abundaron en ello la Historia Silense y Lucas de Tuy. Sobre la omisión del lugar de sepelio en los textos astures, Mattoso 1993, pp. 80-82. Para Linehan 1994, pp. 448 y ss. León desplegó una débil autoafirmación como capital en los siglos X-XII, Ruiz Asencio 1973, pp. 279-286; Fernández 1978, p. 51; Carriedo 2007, pp. 395-456; Henriet 2012.

${ }^{16}$ Inicialmente sepultado en la sede de Astorga, Alfonso III fue transferido a Oviedo al menos a inicios del s. XI, junto con su esposa Gimena. Pérez de Urbel 1952 (versión pelagiana) p. 308. La versión silense del texto de Sampiro, paradójicamente, omite la alusión a Astorga, pero la Historia Silense sí la incorpora. Pérez de Urbel, González 1959, p. 152. Acaso Alfonso III reposó en el sarcófago romano de San Justo de la Vega (Museo Arqueológico Nacional, Madrid), sito en la sede maragata en el s. X.

${ }^{17}$ Sobre la muerte y funerales regios en la alta y plena Edad Media, Prada, Vidal 2009, p. 244.

${ }^{18}$ Ordoño II cedió al obispo Frunimio "avorum et parentorum meorum habueron palatia intus civitas Legionensis”. Morales 1765, p. 53. Risco 1796, pp. 223-225 y 435; 1792, p. 171. Pérez de Urbel 1952,p. 311.

${ }^{19}$ Aunque algún autor prefiera referirse a otros textos posteriores al mío que se hacen eco de la propuesta sin significar su origen. Cfr. Prada, Vidal, 2009, p. 253.

${ }^{20}$ Valdés et al. 1994, pp. 20-25; Boto 1995, pp. 43-50; Bango 2004, pp. 48-51; Carrero 2004, pp. 27-32.

${ }^{21}$ Pérez de Urbel 1952, p. 318, en las dos versiones. El Silense, en la suya propia, calla el lugar de sepelio: "Ordonius pius et gloriosus rex debitum carnis persoluit, anno VIII ${ }^{o}$ regni sui, mensibus duobus, cuius membrorum cineres sepulcrum circumclaudit" (pp. 158-159).

${ }^{22}$ Pérez de Urbel 1952 (versión pelagiana), p. 319.
} 
Entiendo que fue el propio Ordoño II quien eligió la catedral de Santa María como lugar de inhumación. Para el cronista Legionense -y los que le siguieron- estaba fuera de dudas que era $s u$ catedral, desde todos los puntos de vista. Los antepasados de Ordoño II habían recibido sepelio en una catedral, porque San Salvador de Oviedo ya lo era en tiempos de su padre. Este factor constituía un argumento más para optar por el templo episcopal, que disponía ya de unas reliquias de producción propia ${ }^{23}$. Acaso Ordoño II fue el primer rey leonés -e hispano- que se enterró ad sanctos. Pero incluso aunque así fuera no puede concluirse que la elección del lugar de enterramiento fue motivada por una pulsión devocional. El criterio político fue más determinante, como en sus predecesores. En el primer tercio del s. X el templo relicario por excelencia era la basílica compostelana, pero ningún miembro de la familia regia contempló la posibilidad de enterrarse allí. Sólo se considerará con Fernando II, y porque las circunstancias políticas y espirituales convergieron ${ }^{24}$. La devoción sí impulsó, en cambio, a Alfonso V (resguardado por la mandíbula del Bautista) ${ }^{25}$, y todavía de modo más explícito a Fernando I y Sancha (San Isidoro, San Pelayo y San Vicente) ${ }^{26}$.

Ordoño II, en suma, fue sepultado prácticamente en su palacio, reorganizado y consagrado para dar lugar a una catedral. Casi podríamos afirmar que reposó donde vivió. El suyo fue un cementerio áulico por doble motivo, más allá de la morfología del ámbito que le guareciera.

El replanteamiento del palatium regii leonés requirió una nueva sede. Ramiro II, tras su conflicto cainita con Alfonso IV (†933) inhumado en Riuforco ${ }^{27}$, reinstaló el vértice político de la ciudad en su sector meridional, cerca del Arco Rege ${ }^{28}$. El nuevo conjunto contó con un admirable cenobio: monasterium infra urbem Legionensem mire magnitudinis construxit in

${ }^{23}$ El cuerpo del obispo San Froilán (900-905) fue depositado en la catedral por mandato de Ordoño II. Ante las algazúas agarenas sus huesos se guardaron preventivamente en 990 en Valdecésar (León). Estas traslaciones de reliquias desconcertaron a Risco 1796, pp. 189-200. Con el encomio habitual, Tamayo 1659, p. 390.

${ }^{24}$ Boto 2012a, pp. 535-565. La contrapuesta apoyatura de Sancho III en Toledo y Fernando II en Santiago en Dectot 2009, pp. 86-95.

${ }^{25}$ La reliquia llegó de Roma antes de la muerte del rey (1028). No consta que él viajase allí. Fernández del Pozo 1999, pp. 225-226.

${ }^{26}$ Henriet 2002, pp. 334-350; Sánchez Candeira 1999, pp. 216-217. Fernando I escenificó un particular ars moriendi, con un protocolo ut sanctus Isidorus (Bishko, 1965, pp. 47-59; 1984, pp. 47-59) y se inhumó ad sanctos.

${ }^{27}$ Lucas de Tuy, Puyol 1926, p. 314; Lucae Tudensis 2003, p. 258. Se le inhumó en San Julián de Torío según la dudosa alusión de Rodrigo Jiménez de Rada 1987, p. 153. La noticia en Alonso 2005, n. 24.

${ }^{28}$ Sobre el palacio de Palat de Rey, Campos, Pérez 2006, pp. 35-42; Torres 2010, pp. 16-31; Rodríguez 1972, pp. 514-525; Prada, Vidal 2009, pp. 254-255. 
honorem Sancti Salvatoris iuxta palacium regalis ${ }^{29}$. Muerto en 951, Ramiro II sepultus fuit in sarcofago iuxta ecclesiam sancti Salvatoris ad cimiterium quod construxit filie sue Regine domne Geloire ${ }^{30}$. Sampiro atribuye a Elvira, primera titular del Infantaticum leonés y activa gestora del mismo incluso tras la muerte de su hermano menor (959-976), la organización del cementerio en el atrio del monasterio ${ }^{31}$.

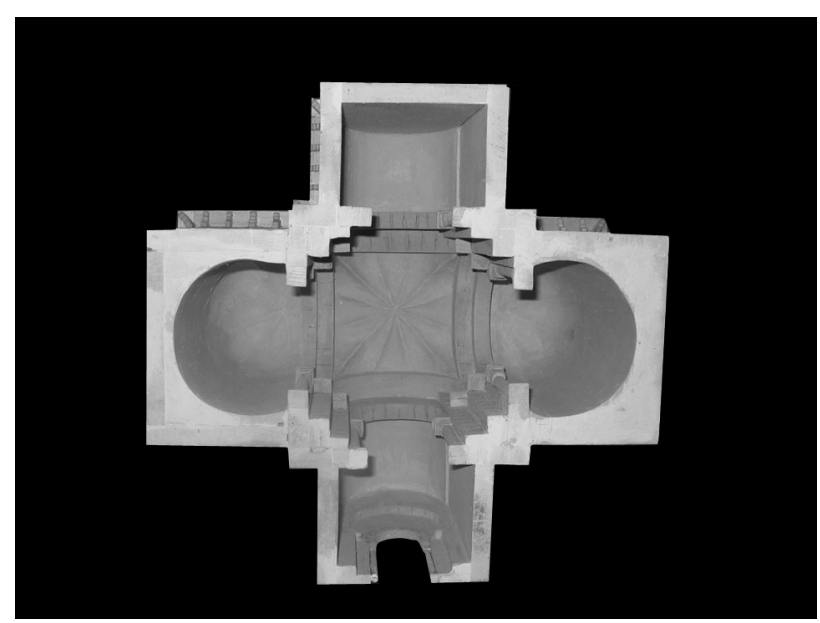

Fig. 1. Planta de la iglesia monástica de San Salvador de Palat de Rey.

Debió ser Ramiro II quien optó por el monasterio de San Salvador. Este nuevo camposanto difiere de los precedentes en tres aspectos: $1^{\circ}$ es un cenobio y no una catedral (Alfonso II, Ramiro I, ... /Oviedo; Ordoño II/León; Alfonso III/Astorga), por lo que la intercesión espiritual sería procurada por monjas, y no por socii o monachi catedralicios; $2^{\circ}$ el cuerpo del soberano se situó en el cementerio sito al cabo del santuario del Salvador; $3^{\circ}$ Sampiro explicitó la deposición del cadáver regio en una cista marmórea romana reutilizada $^{32}$, pieza que subrayaba la relevancia del monarca y punto focal del nuevo panteón dinástico. No en balde, su primogénito Ordoño III $(† 956)$ Legione sepultus fuit iuxta aulam sancti Salvatoris, secus sarcophagum patris suis

${ }^{29}$ Pérez de Urbel 1952, p. 329. Retengamos que "mire magnitudinis" calificaba al monasterio, no sólo a su iglesia.

${ }^{30}$ Ibidem, p. 332, en las dos redacciones.

${ }^{31}$ Carriedo 2001, pp. 118-137.

${ }^{32}$ Moralejo 1984, pp. 187-203. 
Ranimiri regis ${ }^{33}$. En ese lugar reposó también el hijo menor, Sancho I (†966), que Legionem secus patrem suum in ecclesia sancti Salvatoris sepultus fuit ${ }^{34}$, barrunto que con la batuta de su hermana la infanta Elvira.

La fábrica de Palat de Rey contaba con planta en cruz griega -con ábsides de leve herradura en los dos brazos del eje-, según planteó GómezMoreno y certificó arqueológicamente F. Miguel ${ }^{35}$. La planimetría de esta obra pudo haber tenido un correlato en el mausoleo de San Fructuoso de Montelios y acaso -lo apunto con todas las reservas- en el edificio tri o tetraconque sito en el claustro catedralicio de Oviedo y del que se exhumó la exedra septentrional ${ }^{36}$. Aunque no sea un enunciado axiomático en la arquitectura medieval, la planta central de Palat resulta idónea para usos funerarios, al modo de los memoriales de Ravena o Braga, herederos de una compleja tradición cementerial romana ${ }^{37}$. Quizá por eso, Martínez Tejera cuestionó que el cimiterium que construxit Elvira estuviera en el exterior. Para él, se trataba de un edificio cerrado. Pero si aceptáramos que la fábrica que hoy denominamos Palat de Rey fue una construcción funeraria, habría que interpretar que ese panteón estaba iuxta ecclesiam sancti Salvatoris (Sampiro) y habría que suponer, además, que el templo de San Salvador, tras desaparecer sin dejar huella, cedió su titularidad al cementerio. No es asumible que Sampiro, testigo personal de los monumentos que reseñó, silenciase la entidad de un mausoleo presuntamente independiente ni que empleara arbitrariamente los adverbios de lugar. Entiendo, pues, que el cementerio se habilitó en el circuito exterior del templo de Palat de Rey, no en el interior de un edificio autónomo. El edificio de planta central parcialmente conservado es la iglesia de San Salvador. En ella se siguió el esquema espacial de santuario, nave (con acceso lateral), contraábside y, fuera, cementerio. La exedra de poniente constituye un severo interrogante. Martínez Tejera entiende que se suplantó el pórtico por el contraábside y este

\footnotetext{
${ }^{33}$ Pérez de Urbel 1952, p. 334, versión pelagiana. La versión silense (Pérez de Urbel, González 1959, p. 169) emplea iuxta en lugar de secus. Aunque secus en origen alude a lo realizado incorrectamente, para los cronistas del XI y XII acabó significando inmediatez. Lucas de Tuy altera las preposiciones: "Legione quiescit iuxta patrem suum in aula sancti Saluatoris". Lucae Tudensis 2003, p. 262.

${ }^{34}$ Ibidem p. 339, en la versión pelagiana; omitido en la Silense. Para el Tudense "Legione iuxta patrem suum sepultus est in ecclesia sancti Salvatoris". Lucae Tudensis 2003, p. 264.

${ }^{35}$ Gómez-Moreno 1919, pp. 177-178; Miguel 1996,p. 139 sugiere que el contraábside y el crucero se construyeron con posterioridad al ábside mayor y los brazos transversales. Para Miguel el edificio cruciforme fue el templo de San Salvador y para Martínez Tejera el cementerio. Las fuentes no diferencian entre panteón e iglesia.

${ }^{36}$ García de Castro 1999, p. 65; García de Castro, Ríos 2004, p. 272.

${ }^{37}$ Más ejemplos en Martínez 2004,p. 109-187.
} 
por la habitatio sepulchrorum ${ }^{38}$, para respetar la prohibición bracarense (561). No es fácil discernir los criterios que rigieron la anexión o la segregación de espacios adyacentes, operados sin formar parte del espacio cultual. No hay duda de que en una liturgia espacialmente dinámica la visita de las áreas cementeriales, intramuros o extramuros, constituía una parte sustantiva del protocolo de oficios particulares. En el caso de Palat, ningún argumento documental o arqueológico permite presumir que su contraábside desempeñó una función funeraria -como tampoco la tuvo el de Mazote- ${ }^{39}$. Sabemos que el contraábside de Peñalba, construido con la nave, fue un proyecto operado para un destinatario, el eremita obispo Genadio, al que se le reconoció una instantánea santidad. En Palat de Rey lo más significativo es que -salvando el indescifrable caso de Ordoño II- aparece (¿o reaparece?) un cementerio regio en el circuito de la iglesia, obediente al I Concilio de Braga, que siguió en vigor en toda la península hasta fines del siglo XII.

Ramiro III (†985) vero reversus est Legioni: ubique propio morbo discedens afirma Sampiro en sus dos versiones textuales. Sin embargo, la pelagiana añade que, pese a haber fallecido en la capital, in Destriana sepultus fuit $^{40}$. El Silense, en su propia crónica, nada indica, de manera que la referencia parte sólo de Don Pelayo.

De Vermudo II (†999) Sampiro afirma - versión silense- que falleció en el Bierzo ${ }^{41}$. El obispo Pelayo no aludió a este monarca y la Historia Silense lo menciona de pasada, sin indicar lugar de óbito ${ }^{42}$. Lucas de Tuy afirmó que Alfonso V lo trasladó desde la villa de Villabona a León. Nada de ello dijo Sampiro, siempre preciso al especificar los panteones regios, y más el de su amigo personal Vermudo II. Más abajo retomo este punto.

Según la interpolación del obispo ovetense Pelayo ${ }^{43}$, fue Vermudo II quien prescribió la traslación de los cuerpos de los santos y los reyes sitos en León (Ordoño II, Fruela II, Ramiro II, Ordoño III, Sancho I y sus respectivas esposas) y Astorga (Alfonso III y Gimena) hasta Oviedo ${ }^{44}$. La medida salvaguardaba los mayores tesoros espirituales e ideológicos del reino de los

\footnotetext{
${ }^{38}$ Bango 1992a, pp. 100-102. Martínez 1993b, passim sostiene un reemplazamiento funcional -en particular, funerario- del pórtico por el contraábside. Sobre el contraábside de Peñalba, Martínez 2004; 2010. Senra 1997,pp. 122-144 advierte uso sepulcral de los pórticos románicos con o sin conexiones cluniacenses. Lectura global en Dierkens 2002, pp. 495-503.

${ }^{39}$ Martínez 1993b, pp. 155-157; 1993a, pp. 163-215; 2010.

${ }^{40}$ Pérez de Urbel 1952, p. 343; Lucae Tudensis 2003, p. 266.

${ }^{41}$ Pérez de Urbel 1952, p. 346:

${ }^{42}$ Pérez de Urbel, González 1959, p. 176.

${ }^{43}$ Una lista completa de las interpolaciones de Pelayo en Fernández 1995, pp. 341-347.

${ }^{44}$ Huici 1913, I, p. 313-316; García de Castro 1995, pp. 402-404; Carriedo 2006, pp. 12-14, argumenta por qué es creíble el traslado, aunque Pelayo errara algunas identidades.
} 
eventuales estragos de Almanzor en 994. Las sietes techae (es decir, thecae) que transportaban los huesos de reyes y reinas se instalaron en Santa María del rey Casto, según Pelayo. A partir de las referencias de los cronistas del siglo XVI, Selgas advirtió en el muro norte sendos arcosolios de las reinas Urraca (viuda de Ramiro II) y Elvira (viuda de Ordoño II) ${ }^{45}$. El resto del lote sepulcral, desactivada toda amenaza a principios del siglo XI, habría regresado al cementerio de San Juan de León, salvo Ordoño II, depositado presuntamente en la catedral legionense.

Del testimonio del obispo Pelayo me parece relevante la posibilidad de que los cuerpos de unos laicos -aunque soberanos- hubieran ocupado las naves, ante sepulchra priorum regum ${ }^{46}$, sin segregación mural ni funcional con el resto del espacio cultual. No existen precedentes para este hecho y, por ello, cabría dudar de su factibilidad. Pero el prelado, a menudo falsario, no habría contradicho los criterios considerados por la Iglesia de su tiempo para administrar los sepelios regios. La distribución escenográfica que relata -tumbas de reyes y reinas sitas, de modo estable o provisional, en el aula eclesiástica- nunca habría sido considerada por sus potenciales lectores si no cupiese tal posibilidad. Así, considerando al obispo Pelayo, concluyo que los sepulcros de los soberanos leoneses - pero sólo estos y por causa sobrevenidatransgredieron el precepto del I Concilio de Braga (561).

\section{LA CONCIENCIA DINÁSTICA Y EL NUEVO PANTEÓN DE SAN JUAN BAUTISTA}

La tercera necrópolis regia de León fue iniciativa de Alfonso V. Reunió los cuerpos diseminados por la ciudad - ¿había alguno, en realidad?- y fuera de ella -presuntamente sus padres- para fijar un nuevo panteón dinástico, según Lucas de Tuy ${ }^{47}$. A la luz de sus palabras, cabe interpretar que, por primera vez, un monarca concibió la disposición y agrupación, desplazando

\footnotetext{
${ }^{45}$ Para Selgas 1890, pp. 308-310 las tumbas fueron "esparcidas por las naves y especialmente junto al panteón".

${ }^{46}$ Sánchez 1924, p. 67. Cf. Alonso 2007, § 13, analiza las intenciones del prelado. Además, Dectot 2005, p. 86.

${ }^{47}$ Lucas de Tuy 1926, p. 89; Lucae Tudensis 2003, p. 275: "fecit etiam ecclesiam sancti Ioannis Baptistae in ipsa urbe ex luto et latere, et collegit omnia ossa regum et episcoporum, quae in ipsa erant ciuitate, et in ipsa ecclesia sepeliuit ea simul et super ea hedificauit altare ad honorem sancti Martini episcopi et confessoris. Deinde transtulit ossa patris sui Veremundi regis, qui sepultus fuerat in Berizo in Villabona, et sepeliuit ea in occidentali parte ipsius ecclesiae in sepulcro marmoreo una cum matre sua regina domina Geloyra. Restauravit etiam iuxta eandem monasterium sancti Pelagii, quod ab Agarensis fuerat destructrum". En el relato de A. de Morales no constan otros predecesores que los padres de Alfonso V. Es espuria la tradición de que éste recopiló los huesos de Alfonso IV y de Ordoño IV, quien "vivens inter sarracenos mansit, et emulando penas persoluit". Pérez de Urbel 1952, p. 337.
} 
y vinculando las tumbas de otros. Además, Alfonso V propició un panteón para el futuro, como Alfonso II en Oviedo, Ordoño II en la catedral leonesa o Ramiro II en Palat de Rey. Los azarosos acontecimientos y las mermas padecidos por la urbe y el reino en la última década del $\mathrm{s}$. X pudieron influir en la decisión de Alfonso V. Además, la nueva reliquia del Bautista sin duda actuó como polo de atracción y catalizador de amparo terrenal y escatológico.

De ser cierta la emigración de los cuerpos regios a Oviedo, Alfonso $\mathrm{V}$ se habría encontrado una ciudad desprovista de monumentos de su linaje. $\mathrm{O}$ don Pelayo o don Lucas mienten: o los huesos de los reyes migraron a Oviedo y el Noble no aglutinó ningún esqueleto, o nunca cruzaron la cordillera y sí los tomó de Palat de Rey y de la catedral.

La contradicción documental afecta incluso al cuerpo del padre de Alfonso V. El Tudense da por sentado que desde 999 Vermudo II permanecía en el Bierzo y que desde allí lo trasladó el Noble hacia 1010-1020 para depositarlo en el panteón de San Juan Bautista. Vermudo II había solicitado tumba en el cenobio de Carracedo y allá se creía que estaba aún en el siglo $\mathrm{XII}^{48}$. Sin embargo, el obispo Sampiro, amigo privado de Vermudo II, requirió en noviembre de 1042 ser inhumado en la catedral de Santa María y San Cipriano de León -y no en su propia sede asturicense- solo porque allí estaba la cista y el cuerpo del monarca ${ }^{49}$. Sampiro solicitó una tumba ad regem -no sólo ad sepulcrum regi-, con lo que explicitó dos perfiles de su afecto leal: pretender ser recordado a los pies de su rey estimado y advertir que los cuerpos de los monarcas eran dignos de honra y veneración, en una transferencia al cuerpo del rey de las actitudes que suscitaban los despojos de los santos. No habrá que soslayar que la catedral de León perdió los huesos del obispo santo Froilán en 990 porque Vermudo II permitió su dislocación preventiva a Valdecésar, de donde no regresaron hasta 1175. Para Sampiro, el primer autor de la cronística asturleonesa que asentó la conciencia y la memoria del locus regi, el cuerpo del rey desempeñó un papel sustitutivo al santo. Sampiro no pudo errar al situar la tumba de Vermudo II en el aula catedralicia, porque estaba en juego su propio destino mortuorio. Solo cabe una conclusión: el pasaje del Chronicon Mundi del Tudense yerra en toda su extensión y debe impugnarse su veracidad histórica.

\footnotetext{
48 "Mando ibi corpus meum in sepulturam"; y en 1138 la infanta Sancha "domno Beremundo rege qui in eo sepultus est, usque diem hanc". Martínez 1997, I, pp. 35-37. Ambas noticias en Carriedo 2006, pp. 18-19, 33, 39-40 y 68-69. Vermudo II estaba en San Isidoro en el primer tercio del s. XIII y en el siglo XI en la catedral leonesa, de acuerdo con Sampiro; imposible que reposara en Carracedo, aunque sus monjes se lo aseverasen a la infanta Sancha.

${ }^{49}$ Pérez de Urbel 1952, pp. 476-478: "ad sancte Marie uirginis et sancti Cirpirani aepiscobi, ubi corpus manet ad ipsa aulam umadi nostrum, sive (etiam et corpus) rex domno Ueremudus; et inde aueamus ueniam delictorum nostrorum”.
} 
Reconsideremos a Alfonso V. Infiero que no llegó a organizar un panteón partiendo de sus predecesores, para enlazar pretérito y futuro, sino desde su personal presente. Así, en 1042 en San Juan Bautista estarían depositados solo Alfonso V con su mujer Elvira y Vermudo III con la reina Jimena. Que los restos de Vermudo II acabaron llegando a San Isidoro es incuestionable porque allí los sitúa el Tudense y porque lo certificó Morales ${ }^{50}$. Pero en la primera mitad del s. XI la catedral de León contaba con un panteón real compuesto por Ordoño II -si es que había ido y regresado de Oviedo- y por Vermudo II. Más aún: la tumba de este último se encontraba ad ipsa [sic] aulam y no en el exterior. Recordemos que Sampiro había detallado que la tumba de Ordoño II se localizaba in aula sancte Marie. Se diría que las preposiciones pretenden dibujar una organización dispar a la de Palat de Rey. En esta iglesia las tumbas se colocaron iuxta San Salvador, si bien la de Sancho I hincó in ecclesia, aunque junto a su padre, y por tanto en el exterior ${ }^{51}$. Me pregunto si en las catedrales rigió algún criterio diferente al adoptado y exigido en los monasterios, de modo que los cuerpos regios podían entrar más fácilmente en las naves ${ }^{52}$.

Alfonso restauró el templo de San Juan Bautista y ante las puertas orquestó $s u$ cementerio, nuevo panteón dinástico de la ciudad y del reino. En su inmediación se encontraba la casa de San Pelayo, atendida por monjas, en cuyo atrio había sido alojado de nuevo el panteón episcopal ${ }^{53}$, presidido por el altar de San Martín. Las tumbas de los reyes y reinas pasados, presentes y futuros se encontrarían protegidas por el Precursor y abrigadas por los sepelios de los prelados. De manera calculada, se escenificó la imbricación soberanos y prelados a fin de encumbrar memorial y escatológicamente la monarquía leonesa ${ }^{54} \mathrm{y}$, por ahí, de la pervivencia secular de su reino. La solución topográfica de San Juan Bautista difirió de la de Palat, de Santa María o de Oviedo (con reyes al norte de San Salvador y obispos al sur), pero resultó análoga a la consumada en algún caso por las monarquías franca y anglosajona. En Santiago no consta si Gelmírez fue enterrado cerca o lejos de Raimundo de Borgoña, sito en el flanco norte, como los reyes y nobles en San Juan de la Peña.

\footnotetext{
${ }^{50}$ A fines del s. XVI Jerónimo de Llamas menciona la sepultura de Vermudo II: "Esta aora en sant Isidro, en la capilla del claustro que llaman de santa Catherina. Está en un lucillo de mármol liso, el 1 de los doce que está en la vanda delantera". Carriedo 2006, p. 77.

${ }^{51}$ No puedo resolver esta contradictio in terminis, pero juzgo que pesa más el testimonio de la tumba de Ramiro II. Si en algo pudiera ilustrar el Tudense el empleo de la preposición en Sampiro, acabamos de ver (n. 47) que "in ecclesia" pasa a ser "in occidentali parte ipsius ecclesiae" sin mayor conflicto.

${ }^{52}$ La respuesta no puede ser positiva y generalizada. En Compostela el arcosolio de Raimundo de Borgoña se fijó en el exterior del transepto norte. Castiñeiras, Nodar 2010, pp. 83-95.

${ }^{53}$ Boto 2009, p. 160. En 966 el panteón episcopal ya estaba junto a la iglesia de san Pelayo. Así, Alfonso V volvía a reunir los cadáveres episcopales en su viejo depósito. Boto 2012b.

${ }^{54}$ Isla 2010, pp. 57-77.
} 
Las mismas incertidumbres topográficas o de dimensiones de Palat de Rey (con sus tumbas al exterior de San Salvador) empañan la configuración material del dextrum de San Juan Bautista. Palmarias evidencias revelan que la nave del templo de Fernando I y Sancha, consagrado en 1063 a San Isidoro, se erigió sobre los perfiles y las fachadas de la iglesia de Alfonso $\mathrm{V}^{55}$. Ante las puertas oeste y norte del San Juan de ca. 1020 y del San Isidoro de 1063 se extendía un área acotada pero sin inflexiones, que englobaba el pretérito intervallum campamental romano ${ }^{56}$. Las tumbas de Alfonso V (†1028) -cerca de su padre y su madre, afirmó el Tudense ${ }^{57}$ sin base histórica ${ }^{58}-$, de Vermudo III y de Fernando I $(\dagger 1065)$ y de Sancha $(† 1067)$ ya se ubicaban a los pies de la iglesia ${ }^{59}$.

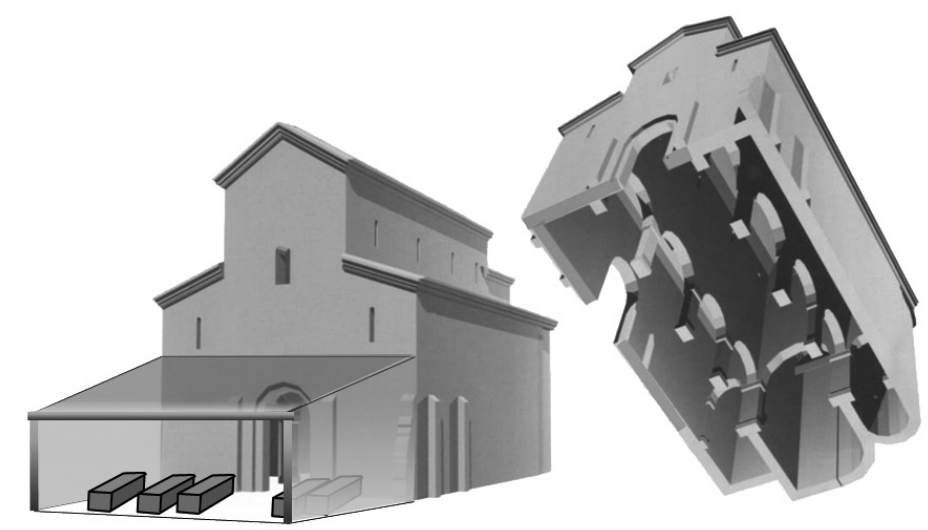

Fig. 2. Planta de San Juan Bautista de León, iglesia consagrada en 1063, con cementerio ante la fachada.

${ }^{55}$ Boto 2009, pp. 174-183.

${ }^{56}$ Prada, Vidal 2007, pp. 599-688, sin justificación evidente, retoman la tesis de E.A.R. Brown, que analizó el culto a los cuerpos regios (tutores del reino y de sus súbditos) en SaintDenis desde los siglos XII-XIII.

${ }^{57}$ Lucas de Tuy 1926, p. 336. Cfr. Fernández del Pozo 1999, p. 223.

${ }^{58} \mathrm{La}$ indicación del Tudense es inequívoca: en 1230 los restos de Vermudo II y Elvira reposaban en una cista marmórea bajo las bóvedas de San Isidoro. ¿Ese mismo sarcófago romano las guardaba ya en 1042 en la catedral de Santa María? ¿Era el mismo que empleó Ramiro II, vaciado tras su presunto traslado a Oviedo en 996 ?

${ }^{59}$ Las circunstancias y motivaciones bajo las que Fernando I aceptó enterrarse en San Isidoro, junto a sus suegros y sus cuñados en la Historia silense. Pérez de Urbel, González 1959, p. 197. Caldwell 2000, pp. 1-48. 
Dado que el cementerio se situó ante la puerta oeste de la iglesia, la historiografía ha querido reconocer en San Juan Bautista una continuidad y actualización del panteón astur, o al menos de su sucesión lineal de ámbitos, de este a oeste: santuario, naves y cementerio privilegiado ${ }^{60}$. Pese a ello, Alfonso V no buscó un subterfugio para introducir el panteón dentro de las naves de San Juan. Como ocurrió en Palat de Rey, hincó los sepulcros extra portas, de acuerdo con los cánones visigodos.

El cubículo funerario de Oviedo se efectuó de modo sobrevenido, hermético y macizo, pero en la nave. La voluntad historiográfica de homologar el atrio de San Juan con el mausoleo de Oviedo ${ }^{61}$ y la tentativa de equiparar las funciones de estos recintos funerarios encuentra dos apoyaturas: la ubicación occidental de ambos y su carácter restringido, refractario a los laicos. Los cementerios de León y Oviedo compartieron dos factores primordiales: la distribución axial de presbiterio, naves, cementerio y la ocupación por miembros de la dinastía regia (incluido el infausto conde García).

Sin embargo, difieren en todo lo demás. No obstante, ambos panteones tuvieron menor parentesco de lo reiterado enfáticamente y difirieron en tres rasgos: incorporación $v s$. segregación en el cuerpo físico del templo; hermetismo $v s$. permeabilidad de paso; refracción severa al acceso vs. restricción a la comunidad. El cementerio de San Juan se emplazó al exterior, en el lugar de los contraábsides aunque ignoramos si a descubierto ${ }^{62}$ y iuxta templum; era funcionalmente autónomo aunque vinculado estructuralmente a la iglesia y estaba segregado del espacio cultual por una puerta. Así, en su topografía, el camposanto de Alfonso V consideró el precedente leonés de Palat de Rey y no el ovetense. Desembocamos en un argumento capital para este trabajo: los cementerios regios de León de la segunda mitad del s. X y la primera del s. XI no reproducen el planteamiento del panteón ovetense ni el de los visigodos, desconocidos ${ }^{63}$. No hay constancia material de un cierre mural del panteón fernandino por sus perfiles norte y sur ${ }^{64}$. Para el lado oeste, el rastreo de georradar efectuado el año 2007 proporcionó algunos indicios. Si contó con pilares

${ }^{60}$ Bango 1992a, pp. 100-101.

${ }^{61}$ Alonso 2007, § 10; Prada, Vidal 2007,p. 605. En relación con las inhumaciones contiguas al templo, invocaré el enterramiento del navarro Sancho Garcés I (905-925) en el pórtico de San Esteban ("Sepultus sancti Stefani portico...") según recoge el Initium Regnum Pampilonam. Su hijo y sucesor, García Sánchez I, recibió sepultura (970) "in castro sancti Stefani...", esto es, San Esteban de Monjardín. Según Martínez 2008, p. 221 esta es la primera mención documental de un porticus. Su emplazamiento lateral, exterior y transitable, nada tiene que ver con el habitáculo funerario de Oviedo.

${ }^{62}$ No hay testigos de un cierre mural del cementerio de Alfonso V. Los supuestos restos son, en realidad, los fundamentos de los muros vigentes. Boto 2009, p. 165, n. 77.

${ }^{63}$ Alonso 2005, pp. 361-375.

${ }^{64}$ Boto 2012b, pp. 101-103. 
y techumbre, las vigas se empotraron a la altura de la bóveda actual, porque no hay mechinales en otro lugar. El mausoleo de San Juan-San Isidoro, segregado y exógeno como lo será desde 1080 el de Sahagún, incrementó su circunscrita similitud con el de Oviedo sólo después de 1073, cuando se reformuló su morfología y fue construido con léxico arquitectónico románico. Solo entonces el recinto funerario quedó materialmente delimitado, cubierto y superpuesto por una tribuna de uso regio, o cuando menos principesco ${ }^{65}$.

Bango asentó que el recinto leonés no fue concebido ni empleado como un acceso transitable al templo, difiriendo así de los macizos occidentales germánicos o francos ${ }^{66}$. Nunca se pudo circular indiscriminadamente in cimiterio Sancti Pelagii Legionensi ciuitas (documentación de mediados del siglo XI), in Legionenssy regum ciminterio (Silense) ${ }^{67}$ o in sepulchris regum (Chronica Adefonsi Imperatoris $)^{68}$.

\section{PALACIOS Y PANTEONES}

La realidad histórica y topográfica debe ser precisada en otra vertiente. Consta una inmediatez física entre el palacio y el panteón regios en distintos enclaves de la ciudad de León ${ }^{69}$. Sampiro detalló que junto al palacio de Ordoño II se instaló la nueva sede catedralicia y en ésta su sepulcro. El conjunto palatino de Ramiro II incluía el monasterio de San Salvador y, adyacente a este, el cementerio ${ }^{70}$. La organización del camposanto de Palat sólo se explica por el afán de reunirlo al nuevo palacio y al monasterio. Dada esta vinculación de residencia y panteón del s. X, se ha supuesto que en el s.

\footnotetext{
${ }^{65}$ Sobre la tribuna de uso regio, Martin 2006, pp. 82-83, quien juzga el "Panteón de los Reyes" un ámbito palatino, retrasa su uso cementerial a fines del s. XII y refuta contenidos penitenciales en los programas visuales promocionados por la infanta Urraca. Contraposición de argumentos y razonamientos en Boto 2012b, atendiendo a las circulaciones $y$ al contenido soteriológico de capiteles y pinturas.

${ }^{66}$ Bango 1992a, p. 105.

${ }^{67}$ Cavero 2012, cree que el anónimo autor se detiene sólo en las tumbas de los reyes que le convienen para sus objetivos. Cfr. Isla 2007, pp. 244-246.

${ }^{68}$ Perez de Urbel, González 1959, pp. 197 y ss. Todas las referencias en Prada, Vidal 2007, pp. 611; 2009, p. 258. Documentos de particular interés en Ruiz Asencio 1990, pp. 278-280, docs. 1084 y 1085 . Es revelador que en 1052 el abad Froilán se denomine de San Pelayo y no de San Juan y San Pelayo y que el cementerio era de San Pelayo: "abbas Sancti Pelagii, item cimiterii Legionensis". Para el prelado ambos templos constituían una unidad.

${ }^{69}$ Sobre la relación entre palacios, iglesias y cementerios de la ciudad, Prada, Vidal 2007, pp. 612-618; 2009, p. 255. La tradición europea desde la Tardoantigüedad en Brenk 2007, pp. 101-115; Greci 2007, pp. 116-122.

${ }^{70}$ Campos, Pérez 2006, pp. 35-42. Ambrosio Morales sugirió que el palacio real estuvo bajo el Palacio del Conde Luna, pero Puyol 1926, pp. 31-32 lo descartó.
} 
XI debió reproducirse ese proceder: que junto al templo áulico de San Juan, y de su panteón, estaría el palacio de Alfonso V y el de Fernando I y Sancha. Pero ningún documento lo acredita ${ }^{71}$. La única fuente que ubica un palacio real en León data de 1096 y lo sitúa en el sector suroccidental de la muralla, cercano a la puerta Cauriense ${ }^{72}$. No hay más indicio para considerar un uso y propiedad regios que la Crónica del Emperador Alfonso VII ${ }^{73}$. Este texto alude a los palacios reales que estaban en san Pelayo. ¿La frase confirma el emplazamiento o especifica qué palacios, entre los que poseía el emperador en León, acogieron el certamen? Huelga decir que todos los palacios son del rey -incluso los del Infantazgo- ${ }^{74}$ aunque no se alojase en todos. No logro certificar que el rey de León (de Alfonso V a Alfonso VII) acuarteló su residencia en torno a San Isidoro. La paradoja es que las dos noticias corresponden a los reinados de Alfonso VI y Alfonso VII, soberanos apegados a Sahagún y Toledo. Cabe que el rey empleara el palacio de San Isidoro en los siglos XI y XII, pero lo seguro es que allí residieron las infantas.

Alfonso VI y Constanza de Borgoña, con la que desposó en 1079, organizaron una residencia en torno al monasterio de Sahagún. Cuando enviudó en 1093 donó unos palacios que habían sido de su esposa Constanza para atención de peregrinos ${ }^{75}$. La tumba de Constanza estaba en Sahagún, donde Alfonso VI había decidido ser enterrado ya en 1080, según su testamento ${ }^{76}$.

${ }^{71}$ Estepa 1977, p. 125 remite a los Milagros de San Isidoro (ed. Pérez Llamazares), donde no se explícita un palacio regio junto a San Isidoro. Insiste Colombás 1982, p. 35; Prada, Vidal 2009, p. 252, fig. 6 .

${ }^{72}$ Ruiz Asencio 1990, pp. 604-605, doc. 1291: "multis quoque manet notum necnon et a plurimis est declaratum quod constructe fuerunt tres ecclesias in honorem sancti Iacobi aposti et sancti Marcelli et sancti Adriani inferius Porte Cauriensis, foris murum, subtus palatium regis". Las iglesias estaban "debajo", extramuros o en desnivel.

${ }^{73}$ Pérez 1997,p. 91. Sobre la infanta Sancha, García Calles 1972.

${ }^{74}$ Según el Tudense el aula ocupada por la infanta era real: "Como la dicha Reina Dona Sancha (...) morase en el palacio Real, que estaba pegado a la iglesia de San Isidoro". Llamazares 1924, p. 191; Henriet 2008. El palacio infantático formaba parte de las propiedades regias. Sancha se autoenajenó para cedérselo a la Iglesia, como hiciera Ordoño II. Boto 2012b, pp. 121-123.

${ }^{75}$ Herrero 1998, doc. 914.

76 "Cumque talia cogitanti miseratio divina favisset, piamque mei cordis voluntatem compleri vidissem, elegi ut post mortem meam ibi tumulatus requiescerem; quatinus quem in vita nimio amore dilexi, etiam defunctus foverem". Herrero 1998, pp. 76-79; Gago, Díaz 1991, pp. 40-55; Puyol 1915, pp. 17-18; Gambra 1997, I, p. 445-452; Carriedo 2005, pp. 83 y ss.; Senra 1997, n. 74; Herraéz 2000, p. 57.

Sin embargo, Alfonso VI en 1075 tuvo la intención de enterrarse en la sede burgalesa: "do et concedo corpus meum et animam meam Deo et Sancte Marie burgensis sedis ecclesie, altaribusque ad honorem Beati Iacobi Beatique Nicholai illiccine constructis". Flórez 1771, p. 224; Serrano (1935-1936), I, p. 345; III, docs. 33 y 34, pp. 80-82; Mansilla 1971, docs. 43 y 44, pp. 3031; Garrido 1983, docs. 47 y 48, pp. 101-104. La fórmula literaria de conceder cuerpo y alma en los documentos altomedievales leoneses: Libro de Regla, doc. XLIII, 18 enero 1017, pp. 56-57; Floriano 1981, doc. 30 (1200), p. 170; Domínguez 2000, doc. 38, año 1175, pp. 101-102. 
Panteón y palacio fueron erigidos por la pareja real y al compás. No hubo esa inmediatez de aula y cementerio ni en el Toledo de Alfonso VII ni en la Compostela de Fernando II y Alfonso IX, quienes se enterraron en Compostela por estrategia política y devoción religiosa.

\section{APERTURA Y CLAUSURA DE LOS CEMENTERIOS DINÁSTICOS. SAN ISIDORO Y SAHAGÚN}

El panteón de Santa María de Oviedo agrupó a cinco monarcas y a sus esposas (Alfonso II, Ramiro I, Ordoño I, Alfonso III y García I), el de la catedral leonesa a tres que al final se redujo al primero (Ordoño II, Fruela II y Vermudo II) y en el de Palat cupieron tres reyes (Ramiro II, Ordoño III y Sancho I). En San Juan Bautista, más tarde San Isidoro, fueron inhumados seis monarcas (Vermudo II, que primero estuvo en la catedral de Regla, Alfonso V, Vermudo III, Fernando I, García I de Galicia y Urraca I), amén de reinas consortes, infantas y nobles. Es manifiesta la dificultad por mantener y perpetuar un mismo emplazamiento funerario durante poco más de medio siglo. Hasta 1294, toda vez que un cementerio era sustituido por otro, ningún monarca volvió al precedente, con la única -y sintomática- excepción de Urraca $\mathrm{I}^{77}$. Otro tanto sucederá con los cementerios de Sahagún (Alfonso VI), Toledo (Alfonso VII y Sancho II), Santiago de Compostela (Fernando II y Alfonso IX) o Sevilla (Fernando III y Alfonso X) ${ }^{78}$. La multiplicidad e inestabilidad de las necrópolis regias fue la tónica dominante también en el mundo franco durante el s. XI y en germano durante todo el Medievo. Sin embargo, merovingios, carolingios y otónidas en reiteradas ocasiones sí reabrieron y reutilizaron pretéritos panteones ${ }^{79}$. En los reinos asturiano y leonés -incluso después en la Corona de Castilla y León- los cementerios regios se organizaban, utilizaban y finalmente se clausuraban. En la práctica, una vez abandonados, su uso no fue recuperado por un nuevo soberano. El primero que alteró esta dinámica, por razones concluyentes fue Sancho IV, en el presbiterio mayor de la sede toledana $^{80}$.

\footnotetext{
${ }^{77}$ Ha estudiado la reina Urraca, sepultada junto a todo su linaje, Martin 2005b, pp. 1134-1171; 2005a, pp. 551-578.

${ }^{78}$ Sobre las discontinuidades cementeriales y dinásticas en el medievo hispano, Rucquoi 1995, pp. 163-186.

${ }^{79}$ Dierkens 2003, pp. 45-58. No advierto similitudes entre los usos funerarios asturleoneses y los carolingios y germánicos; al contrario, la clausura sin retorno de los cementerios regios leoneses evidencia divergencias fundamentales con la Europa central.

${ }^{80}$ Gutiérrez 1997,pp. 163-194. Sancho IV proyectó rehabilitar las tumbas de reyes en Oña: Senra 2002b, pp. 141-163; Boto 2012a, p. 555.
} 
El proceso constructivo del llamado Panteón de los Reyes fue bien interpretado por Williams en 1973 y retomado en posteriores estudios ${ }^{81}$. Creo demostrado que la infanta Urraca mandó construir este ámbito tras su llegada al infantazgo en $1072^{82}$. Antes de 1090-1095 ya estaba finalizado, incluido el piso superior empleado como tribuna principesca y el husillo que comunicaba ambos niveles ${ }^{83}$. En el inferior se generó un núcleo con tres naves y dos tramos cada una de ellas, segregados por columnas exentas en el centro y pilares articulados en el perímetro, innovación del sistema constructivo románico muy próximo a las primicias de la catedral compostelana, en 1075. Una nave trasversal de tres tramos suelda este núcleo a la vieja muralla romana. Esta nave perimetral dobla en ángulo y genera un pórtico adherido al muro norte del templo fernandino, en origen más largo que la extensión estilísticamente atribuible a fines del s. XI.

Importa detenerse en dos hechos íntimamente relacionados: $1^{\circ}$ la cronología de la construcción y las tensiones político-familiares que agitaron ese momento; $2^{\circ}$ la temática que despliegan los capiteles del Panteón en consonancia con las circunstancias de su inequívoca promotora.

La entrañable relación entre Urraca y Alfonso alcanzó su momento culminante en 1072, cuando este aglutinó todo el territorio de León y Castilla $^{84}$. Urraca regentó el infantazgo de San Isidoro de 1072 a 1101. Además de gestionar bienes eclesiásticos, era custodia de la memoria de sus antepasados en el marco del recinto funerario dinástico. La defensa de sus propios intereses se trababa directamente con la protección espiritual y política que las reliquias de San Isidoro dispensaban sobre el reino y sobre el cementerio real.

Cluny le suscitó sentimientos encontrados. Urraca sabía que los monjes cluniacenses intercedían por las almas de sus padres -y después por la suya-, pero no estuvo dispuesta a cederles sus propiedades, como hicieron otros entonces. Urraca concedió a Cluny sólo una de sus casas y en un régimen un tanto particular ${ }^{85}$. Por otro lado, el mandato oficial del nuevo

${ }^{81}$ El análisis formal de los capiteles en Robb 1945,pp. 165-177; Salvini 1962, pp. 50-54 fue el primero que sugirió que el Panteón fue operado por Urraca Fernández. Le refrendó Durliat 1962, p. 18. Proyectado a toda la estructura arquitectónica, Williams 1973, pp. 171-184; 1995, pp. 231-258; Senra 1997, pp. 122-144; Valdés 2000, pp. 73-84; Martin 2006, pp. 82-83; Kruger 2006, pp. 36-39; Boto 2009, pp. 162-166; 2012b, pp. 98-118.

${ }^{82}$ Viñayo 1982, pp. 123-135; Walker 1998, pp. 113-138; Henriet 2000, pp. 189-203; T. Martin 2008; Klinka 2008; Boto 2010, pp. 75-82.

${ }^{83}$ Cementerio y tribuna corresponden a un proyecto constructivo, sin cesuras, como argumentaron Gómez-Moreno y Williams. Boto 2012b, pp. 101-118; Dectot 2005, p. 85.

${ }^{84}$ Martin 2009.

${ }^{85}$ Sólo cedió Palat de Rey, en 1079, aparentemente a propuesta del rey, pero Urraca no renunció a la tutela del monasterio. Según Reglero 2008, pp. 164-165 y 325-326, Palat revertió al 
rito $^{86}$ y la adhesión a la reforma gregoriana iban en menoscabo del infantazgo. Si Urraca hubiera asumido los principios reformistas requeridos desde Roma, el infantazgo habría quedado extinto, sin justificación institucional ni funcional. Los nuevos actores del mapa político del reino comprometían la supervivencia de la institución que ella personificaba.

Sin embargo, el mayor riesgo era endógeno. Alfonso VI decidió enterrarse lejos de San Isidoro, primero en Burgos y luego en Sahagún. En San Facundo fue inhumada su primera mujer, Inés de Aquitania ${ }^{87}$, en 1078, cuando aún no había sido designado abad de Sahagún el cluniacense Roberto ${ }^{88}$. En 1080 Alfonso VI ya había testado que erigiría su panteón familiar en la iglesia monástica sahaguntina ${ }^{89}$, impugnando así el continuismo dinástico de San Isidoro $^{90}$. En ese mismo año de 1080 llegó el nuevo abad, Bernardo de la Sauvetat ${ }^{91}$ y se instaló la segunda esposa del rey, Constanza. Esta sobrina de San Hugo vinculó su vida -en el palacio- y su muerte -en el cementerio- a Sahagún. Gambra y George Martin han subrayado el distanciamiento institucional -y quizá emotivo- entre la infanta y el rey durante los años del matrimonio con Constanza de Borgoña, encarnación de todo lo que comprometía la supervivencia de Urraca ${ }^{92}$. El monasterio de San Facundo se configuró como una embajada cultural y espiritual de Borgoña en León, dotada de inmunidad

infantazgo tras una breve adscripción a Cluny. Además, Reilly 1989, p. 115. Sobre Urraca y su interés formal por Cluny y nulo por Sahagún, Gambra 1997, p. 493

${ }^{86}$ Reilly 1989, pp. 118-119 explica que en 1074 Gregorio VII (1073-1085) requirió al "regi Hyspaniae" (epíteto enunciado en Roma y asumido por Alfonso VI) que adoptase el rito romano. Reilly 1989, p. 121 sostiene que el cambio de rito se produjo en 1076. Argumentan que se dictó en el concilio de Burgos en 1080, Reglero 2007, pp. 689-732; Gambra 1997, pp. 541-543. La reconsagración de altares con el nuevo rito permitió que añejas iglesias pudieran acomodarse a una nueva organización y jerarquía. Martínez 1996, pp. 80-85 y 98; 2002, pp. 99-100, n. 54 y p. 106. Los datos que conocemos para estas últimas proceden principalmente del Ordo de Narbona (s. IX), del Anthifonarium Legionense (s. X) y del Pontifical de Roda (s. XI); Gros 1966, pp. 327-401; Flores 1990, pp. 69-80. Sobre la consagración a la romana de pretéritos edificios hispanos, Carrero, Fernández 2005, pp. 385-402.

${ }^{87}$ Morales 1765 , pp. 35-36.

${ }^{88}$ En Sahagún se observaría la regla benedictina "secundum quod fratres Sancti Petri Cluniacensis obtinent”. Véase Reilly 1989, pp. 124 y 135; Mansilla 1944; O'Callaghan 1985 , pp. 101-120; Rucquoi 2010, p. 109.

${ }^{89}$ Senra 1997, n. 74 identificó el recinto como panteón, titulado capilla de San Mancio en el s. XIII.

${ }^{90}$ A pesar de que la cuarta esposa de Alfonso VI, Isabel, y una concubina, Zaida, descansaron en San Isidoro. Lucas de Tuy 1926, p. 383; Gambra 1997, p. 472 duda del testimonio del Tudense. Morales 1765, p. 43 sitúa a Isabel en el Panteón leonés. En Sahagún se conservaba una lápida con su nombre, acaso para acallar su ausencia, como quizá acaeció con Sancho III en Oña. Sobre Zaida, Gambra 1997, p. 441; López Morán 2009, pp. 37-44 y 63-74.

${ }^{91}$ Reilly 1989, p. 132; Gambra 1997, p. 456; Linage 1999, pp. 50 y ss.

${ }^{92}$ Gambra 1997, p. 490. G. Martin 2008; 2009, p. 10 y 16. Sintomáticamente, Urraca dejó de firmar documentación con su hermano a partir de 1080, habitual hasta entonces. La alianza cluniacense de Alfonso VI no halló refrendo en Urraca. 
diplomática y eclesiástica. A pesar de conquistar Toledo, Alfonso VI eligió Sahagún porque deseó enterrarse en Cluny, en su Cluny.

En 1080 la infanta Urraca llevaba ocho años al frente del infantazgo de San Isidoro. Las inquietantes coyunturas conjugadas ese año le apremiarían a culminar la monumentalización del cementerio de San Isidoro, reivindicándolo como el verdadero y legítimo panteón dinástico del linaje regio leonés.

Los proyectos cementeriales y templarios de Sahagún ${ }^{93}$ y de San Isidoro mantienen una elocuente proximidad en tiempo y espacio. Lejos de complementarse, establecieron una fraternal contraposición. Detrás de sendos conjuntos se situaron fuertes personalidades que los concibieron y promovieron bajo ópticas e intereses divergentes. Desde 1079-1080 se consumó una duplicación $-\mathrm{y}$, a la postre, rivalidad- de panteones regios dentro de León: el avalado por el pasado dinástico vs. el alentado por el futuro monástico. Esa contemporaneidad y competencia no tenía precedentes en Hispania; en cambio, duplicidades análogas no faltaron en las sociedades merovingia, carolingia y otónida.

La construcción del cementerio regio de San Isidoro se llevó a cabo en un contexto de adversidades y antagonismos familiares, políticos y eclesiásticos. Impulsado desde el afecto filial, el proyecto de la nueva fábrica reforzaba la primacía y prestigio del recinto funerario isidoriano y suponía un alegato político en pro de la institución del Infantazgo y de la mediación desempeñada por la infanta entre los reyes muertos y su memoria viva. El recinto, sus dependencias perimetrales y el pórtico septentrional se poblaron de capiteles, cuya iconografía ha intrigado a los historiadores del arte desde Gómez-Moreno ${ }^{94}$. La dimensión soteriológica y redentora de las figuras se ha interpretado en un contexto penitencial ${ }^{95}$. Por otro lado, se ha intentado advertir en estos capiteles un restablecimiento de la ecclesiae primitivae forma ${ }^{96}$. Pero es paradójico imaginar a Urraca comulgando con los principios gregorianos, que pretendían su inmolación personal e institucional al condenar la injerencia civil en la gestión de la Iglesia. Las imágenes apuntan en otra dirección.

Los capiteles del cementerio regio leonés que asumieron argumentos bíblicos se distribuyeron con una intencionalidad comunicativa deliberada. Los temas veterotestamentarios (sobre todo, episodios de intervención salvífica de

\footnotetext{
${ }^{93}$ Gómez-Moreno 1925, p. 343 supuso el inicio de la nueva iglesia en 1087. La cabecera fue consagrada en 1099 por el abad Diego (1087-1110), cuyo epitafio afirmaba "opera ecclesiae fundamentum posuit". Gómez-Moreno 1934, p. 157. No es creíble que los cluniacenses de Sahagún hubieran tardado veinte años en consagrar sus altares. $C f$. Herráez 2000, p. 64.

${ }_{94}^{94}$ Gómez-Moreno 1925, pp. 182-184.

${ }^{95}$ El programa del Panteón conmemora a perpetuidad la muerte piadosa de Fernando I, según Moralejo 1989, pp. 40-41; Castiñeiras 2000, pp. 657-693; Walker 2000, pp. 200-225.

${ }^{96}$ Morais 2008. Pero San Isidoro no orbitó institucional, política o artísticamente en torno a Cluny. Además, Walker 1998, p. 122.
} 
Dios: Daniel en el foso de los leones, Sacrificio de Isaac, Balaam, Moisés y el niño paralítico) se dispusieron en el ángulo noroeste del recinto. En cambio, los temas evangélicos, de sanación y resurrección tanto física como espiritual se ubican en el muro este, flanqueando el ingreso a la iglesia, que es la Jerusalén Celeste. Además, proliferan animales con contenido salvífico (pavos bebiendo de una crátera) y otros psicomáquicos (humanos combatiendo bestias). El resto son cestas vegetales. No hay ninguna exaltación visual de la Iglesia ni una proclama del ideario gregoriano, aunque se incorporasen iconografías extraídas del repertorio paleocristiano ${ }^{97}$, que no suscriben las pretensiones papales ${ }^{98}$. La romanidad del cementerio isidoriano se prodiga en los discursos ortodoxos -sin ser vaticanos- en convivencia con emblemáticos rasgos de la tradición oriunda. Viñayo y Walker han advertido algunos motivos y nociones de la liturgia hispana en las pinturas románicas ${ }^{99}$. En San Isidoro la vetera lex se juzgó compatible con una nova vocación internacionalista, explícitamente expresada a través de la acumulación de episodios y santos importados desde más allá de los Pirineos ${ }^{100}$. Las dos tradiciones se conjugaron en un momento en que se asumía una nueva espiritualidad y se reconsideró la raíz de la autoridad eclesiástica $v s$. la política. El pasado concedía la primacía a la Infanta ${ }^{101}$. Por eso ella lo mantuvo en el plano institucional y escatológico, aunque el contexto favorecía a los nuevos aliados del rey, borgoñones y romanos.

Urraca mantuvo durante toda su vida un indeleble compromiso con la causa de su dinastía, amén de sus intereses particulares. Es revelador su denodado esfuerzo por levantar un emporio arquitectónico ${ }^{102}$, dotarlo de un programa visual de exposición pública (Puerta del Cordero) y otro más iniciático en los lienzos pintados del cementerio, y encargar unas fastuosas piezas de arte sacro. Todas estas iniciativas perfilan un férreo carácter. Si en el reino

${ }^{97}$ Sobre la iconografía de la reforma gregoriana, Kessler 2007, pp. 25-48; Pace 2007, pp. 49-59.

${ }^{98}$ Parafraseo el atinado título de Deswarte 2010. Contextualiza el conflicto, Martin 2009, pp. 8 y ss.

${ }_{99}$ Viñayo 1995, pp. 35-36 y Klinka 2007 reconocen en el Panteón vestigios de la liturgia hispana. Walker 2000 advierte la huella hispana en la migración de las almas tras el óbito, el énfasis en el apocalipsis y la penitencia en la liturgia funeraria. En todo caso, la iconografía franca no es necesariamente cluniacense.

${ }^{100} \mathrm{O}$ de temas como el monarca arrodillado al pie de la Cruz. Véase Henriet 2005a, pp. 163-181; 2005b, pp. 209-259.

${ }^{101}$ Un caso concreto de una actitud general perfectamente acreditada durante el Medievo. Sansterre 2004.

${ }^{102}$ Urraca $(† 1101)$ "ampliavit ecclesia istam”, el cementerio y la iglesia románica, en un primer proyecto sin transepto. Su cabecera estaba concluida al menos en 1109. Boto 2009, p. 190. Es inverosímil que no se consagrara ningún altar en San Isidoro antes de 1105-1110; tampoco que en Santiago hubiera altares "romanos" en el deambulatorio y uno "hispano" en el viejo ábside de Alfonso III, hasta 1112. 
se decretaba el cambio litúrgico y se expandía la reforma gregoriana, ella persistía en la salvaguardia de su institución y su familia.

Al mismo tiempo, en Sahagún Alfonso VI alzó un recinto funerario -identificado por Senra- tan ancho como el templo prerrománico. También fue estructurado en tres naves, con dos tramos cada una. Está en discusión si inicialmente estuvo abierto hacia la nave con una o tres puertas. Hay razones para considerar que solo en el siglo XIII se comunicó con el exterior a través de una puerta a oeste. Ya se ha subrayado su similitud formal, topográfica y funcional con el cementerio de León, pese a su contraposición política.
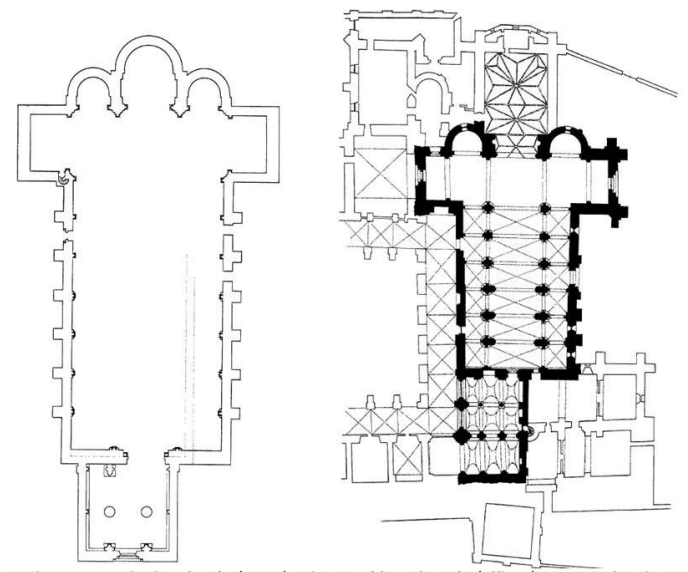

Fig. 3. Cementerios reales de San Isidoro de León y de San Facundo de Sahagún, ca. 1080/1090.

Sahagún se reivindicó como el nuevo y preeminente cementerio con la misma fórmula arquitectónica de San Isidoro, aunque con mayores dimensiones. No descarto que la equivalencia espacial -como una tipología codificada- pretendiera una homologación ideológica.

Constatada esta coincidentia oppositorum -una dialéctica de hermandades opuestas-, cabe rectificar un rasgo del proceso constructivo del cementerio saguntino. Una de las fotos que atestiguan la excavación arqueológica dirigida por Alejandro Ferrant en $1932^{103}$, manifiesta que los muros norte y sur del cementerio no se prolongan orgánicamente en el oriental.

${ }^{103}$ Esteban, García 2007, I, pp. 189-215. El plano que sitúa la excavación de los pilares de las naves en la p. 209. Para Ferrant y Gómez-Moreno el panteón era la nave de una iglesia, de la que no hallaron la cabecera. 


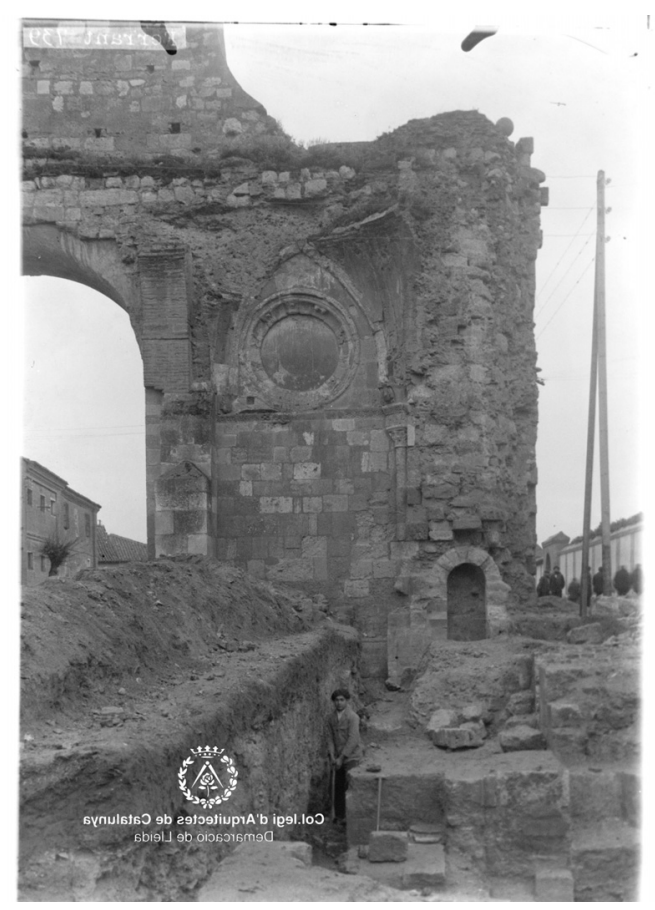

Fig. 4. San Facundo de Sahagún. Iglesia monástica con excavación arqueológica, dirigida por Alejandro Ferrant en 1932. Naves y panteón regio a los pies.

Una cesura vertical revela que el paramento este del panteón fue desmantelado para levantar el hastial de la iglesia en su toda su anchura, en torno a 1213. Así, los muros laterales del cementerio entestaron en la nueva fábrica. Se infiere que los pilares adosados al hastial por su cara oeste -lienzo este del propio cementerio- no corresponden al periodo de Alfonso VI sino al de Alfonso IX. Además, otra fotografía tomada desde la torre del templo muestra los pozos excavados para exhumar los fundamentos de los pilares de las naves. Su alineación desemboca en el panteón en unas coordenadas que no se corresponden con la ubicación fijada en los planos publicados hasta hoy ${ }^{104}$.

${ }^{104}$ Herráez 2000, p. 58 conjetura que la anchura del templo prerrománico y del panteón coincidieran, así como el eje del templo y la nueva puerta oriental. La realidad arqueológica parece otra. 


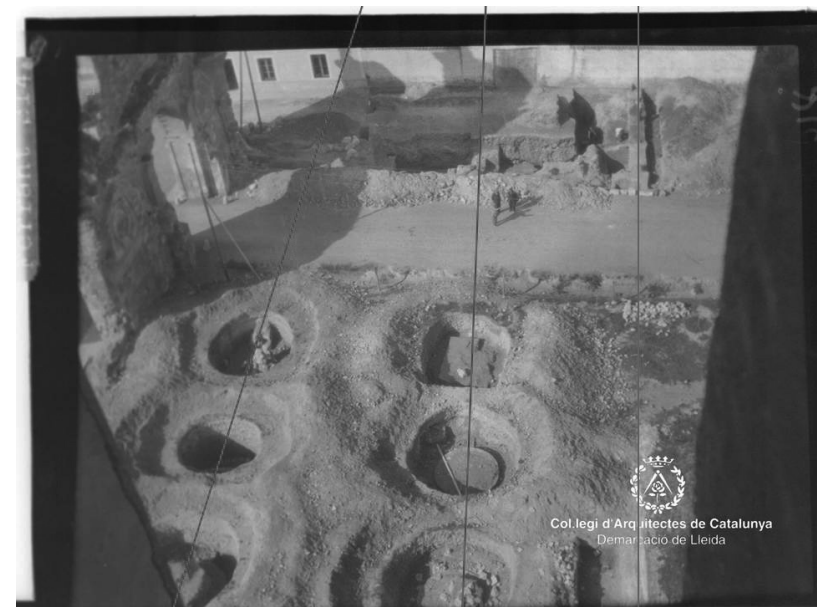

Fig. 5. Archivo del Colegio Oficial de Arquitectos de Catalunya, delegación de Lleida.

La proyección de la fila de pilares de la Epístola cae fuera del perfil del panteón; la de la alineación de los pilares del Evangelio marca el eje del cementerio concluso; el perfil del muro septentrional del templo se alinea con el de la iglesia, como corresponde a la lógica. También en eso se hermana con San Isidoro.

En última instancia, la transformación del recinto cementerial saguntino en un pórtico transitable alteró por completo su naturaleza original y lo homologó a antesalas funerarias cluniacenses, como la de San Zoilo de Carrión ${ }^{105}$. Sucedió a posteriori. Por eso no suscribo que en Sahagún se acoplasen conceptual y topográficamente las galileas francesas con los cementerios a poniente de León y Castilla ${ }^{106}$. En el mundo ibérico, las galileas fueron más numerosas en las catedrales catalanas que en los cenobios leoneses ${ }^{107}$.

${ }^{105}$ Parece cuestionable homologar los cementerios de Carrión y Sahagún desde un primer momento. Senra 2006, pp. 233-267; 2010, p. 152 . Herráez 2000, p. 62 sugieren que la transformación del cementerio en pórtico transitable quiso propiciar la veneración de reliquias. No hallo fundamentos para esta lectura.

${ }^{106}$ Senra 2002a, pp. 336-350; Kruger 2006, p. 51.

${ }^{107}$ Español 1996, pp. 57-77; Sureda 2008, p. 203-225; 2009, pp. 223-238. 


\section{CONCLUSIÓN}

La sucesión temporal de los cementerios regios leoneses es un hecho tan obvio como su inestable localización, inducida por los soberanos por razones institucionales (Ordoño II; Ramiro II; Vermudo II) o políticas (Alfonso V), al margen de los imponderables psicológicos. Sólo Fernando I, ante la determinación de Sancha, redundó cuando pudo variar. Tras el examen de escenarios, estructuras y escenografías resulta palmario que no se asumió reiteradamente un modelo único de panteón monárquico. La heterogeneidad de soluciones y topografías fue la tónica, como también sucedió en Navarra o en Aragón. Sólo Sahagún y San Isidoro asumieron una misma formulación para proclamar, paradójicamente, una aguda oposición política y genealógica. Los objetivos históricos de la infanta Urraca en San Isidoro y de Alfonso VI en San Facundo divergieron: la custodia y la fidelidad a un pasado vigente in locus parentis frente al estratégico enaltecimiento de unos factores históricos nuevos incompatibles con el inmovilismo geográfico y político.

Desde 924 a 1067 los cementerios regios leoneses acogieron unidades familiares y establecieron sucesivas y enlazadas genealogías del poder. La legitimidad no requirió permanecer en el panteón de los antecesores. En León, como en Castilla después, no fue un requisito de estabilidad institucional que los soberanos redundaran en una única necrópolis, como los Capetos y Valois desde el siglo $\mathrm{XI}^{108}$. Sin embargo, la infanta Urraca sí juzgó perentorio monumentalizar el último relicario de una línea dinástica ininterrumpida y, con ello, procurar una reafirmación de la capi$\operatorname{tal}^{109}$.

La ausencia de exequias protocolarias en la realeza leonesa y la multiplicidad de recintos cementeriales constituyen dos rasgos sintomáticos del expediente de personalidad política y escenográfica, suscritos más tarde por los monarcas castellanos.

\footnotetext{
${ }^{108}$ Pero no antes, como se olvida a veces. Prada, Vidal 2009, p. 241. Para los panteones merovingios y carolingios, Alonso 2008, pp. 37-47. Sobre la formación y desarrollo del panteón de Saint-Denis, Erlande-Brandeburg 1975. Ante la dispersión de cementerios régios, Rucquoi 1995 , p. 181 y ss., reconoce toda la Península como un panteón. Sobre las tumbas regias, Guiance 1998, pp. 309 y 314-315.

${ }^{109}$ Linehan 1994, p. 448 y ss.
} 


\section{BIBLIOGRAFÍA CITADA}

Alonso, Raquel (2005), Los enterramientos de los reyes visigodos, en IX Congreso de Estudios Medievales: fundamentos medievales de los particularismos hispánicos, Ávila, Fundación Sánchez Albornoz, pp. 361-375.

Alonso, Raquel (2007), Los enterramientos de los reyes de León y Castilla hasta Sancho IV. Continuidad dinástica y memoria regia, "e-Spania" 3, https://e-spania.revues.org/109 [consulta: 15/12/2013].

Alonso, Raquel (2008), El Panteón de los reyes de Asturias. Modelos ideológicos, en Modelos, intercambios y recepción artística: de las rutas marítimas a la navegación en red, Palma de Mallorca, Universidad, vol. I, pp. 37-47.

Bango, Isidro (1992a), El espacio para enterramientos privilegiados en la arquitectura medieval española, "Anuario del Departamento de Historia y Teoría del Arte" 4, pp. 93-132.

Bango, Isidro (1992b), Los reyes y el arte durante la Alta Edad Media. Leovigildo y Alfonso II y el arte oficial, en Lecturas de Historia del Arte, Vitoria, Ephialte, pp. 19-32.

Bango, Isidro (2004), Catedral de León. Desde la instauración de la diócesis hasta la magna obra de Manrique de Lara, en Yarza, Joaquín; Herráez, María Victoria; Boto, Gerardo (eds.), La Catedral de León en la Edad Media, León, Universidad, pp. 45-57.

Bishko, Charles (1965), The Liturgical Context of Fernando I's Last Days according to the so-called Historia Silense, "Hispania sacra" 17-18, pp. 47-59.

Bishko, Charles (1984), Spanish and portuguese monastic history 600-1300, Turnhot, Brepols.

Boto, Gerardo (1995), La memoria perdida. La catedral de León (917-1230), León, Diputación.

Boto, Gerardo (2009), Morfogénesis espacial de las primeras arquitecturas de San Isidoro. Vestigios de la memoria dinástica leonesa, en Huerta, Pedro (coord.), Siete maravillas del románico español, Aguilar de Campoo, Fundación Santa María la Real, pp. 151-191.

Boto, Gerardo (2010), Las dueñas de la memoria, "Románico" 10, pp. 75-82. Boto, Gerardo (2012a), Aposentos de la memoria dinástica. Mudanza y estabilidad en los panteones regios leoneses (1157-1230), "Anuario de Estudios Medievales" 42/2, pp. 535-565.

Boto, Gerardo (2012b), In Legionenssy regum ciminterio. La construcción del cuerpo occidental de San Isidoro de León y el amparo de los invitados a la Cena del Señor, en Monumentos singulares del románico. 
Nuevas lecturas sobre formas y usos, Aguilar de Campoo, Fundación Santa María la Real, pp. 91-135.

Brenk, Beat (2007), Residenza e capella in epoca paleocristiana e altomedievale, en Quintavalle, Arturo Carlo (ed.), Medioevo: la Chiesa e il Palazzo, Parma, Electa, pp. 101-115.

Caldwell, Susan (2000), Queen Sancha's Persuasion: a Regenerated León Symbolized in San Isidoro's Pantheon and its Treasures en Global Publications. Center for Medieval and Renaissance Studies, Binghamton, Binghamton University, pp. 1-48.

Campos, Dolores; Pérez Gil, Javier (2006), El Palacio Real de León, León, Edilesa.

Carrero, Eduardo (2003), El conjunto catedralicio de Oviedo durante la Edad Media. Arquitectura, topografía y funciones en la ciudad episcopal, Oviedo, Real Instituto de Estudios Asturianos.

Carrero, Eduardo (2004), Santa María de Regla de León. La Catedral medieval y sus alrededores, León, Universidad.

Carrero, Eduardo; Fernandez, Gloria (2005), El conjunto epigráfico de San Miguel de Neila (Burgos) y el ceremonial romano de consagración de iglesias, "Anuario de Estudios Medievales" 35/1, pp. 385-402

Carriedo, Manuel (2001), Una reina sin corona en 959-976. La infanta Elvira, hija de Ramiro II, “Tierras de León” 49/113, pp. 118-137.

Carriedo, Manuel (2005), En torno a los orígenes del monasterio de Sahagún, "Tierras de León" 43/120-121, pp. 65-87.

Carriedo, Manuel (2006), Panteones reales leoneses (ss. X-XIII), en Prada, María Encina (dir.), Estudio Antropológico del Panteón Real de San Isidoro de León, León, Junta de Castilla y León, vol. I, pp. 8-97.

Carriedo, Manuel (2007), Pelayo Tedóniz, obispo de León (1065-1085 y 10861087): ¿Autor de la Historia Silense?, en Fernández Catón, José María (ed.), Monarquía y sociedad en el Reino de León: de Alfonso III a Alfonso VII, León, Monteleón, vol. 2, pp. 395-456.

Castiñeiras, Manuel (2000), El programa enciclopédico de la Puerta del Cielo en el Panteón Real de San Isidoro de León, "Compostelanum" 45, pp. 657-693.

Castiñeiras, Manuel; Nodar, Victoriano (2010), Reconstruyendo la Porta Francigena de la Catedral de Santiago: materiales multimedia para una exposición de arte románico, "Románico" 10, pp. 83-95.

Cavero, Gregoria (2009), Alfonso IX de León y el iter de su corte (1188-1230), "e-Spania" 8, http://e-spania.revues.org/18626 [consulta: 10/03/2012].

Cavero, Gregoria (2012), El discurso de la Crónica silense: San Isidoro y el panteón real, "e-Spania" 14, http://e-spania.revues. org/21612\#bodyftn 19 [consulta: 22/02/2013]. 
Colombás, García de (1982), San Pelayo de León y Santa María de Carbajal. Biografía de una comunidad femenina, Zamora, Monte Casino.

Dectot, Xavier (2005), Tombeaux et pouvoir royal dans le León autour de l'an mil, en Deswarte, Thomas; Sénac, Philippe (dirs.), Guerre, pouvoirs et idéologies dans l'Espagne chrétienne aux alentours de l'an Mil. Actes, Turnhout, Brepols, pp. 81-96

Dectot, Xavier (2009), Les tombeaux des familles royales de la péninsule ibérique au Moyen Age, Turnhout, Brepols.

Deswarte, Thomas (2003), De la destruction à la restauration. L'idéologie du royaume d'Oviedo-León (VIIe-XIe siècles), Turnhout, Brepols.

Deswarte, Thomas (2010), Une Chrétienté romaine sans pape. L'Espagne et Rome (586-1085), París, Garnier.

Diego Santos, F. (1994), Inscripciones Medievales de Asturias, Oviedo, Principado.

Dierkens, Alain (2002), Avant-corps, galilées, massifs occidentaux: quelques remarques méthodologiques en guise de conclusions, en Sapin, Christian (ed.), Avant-nefs et espaces d'accueil dans l'église entre el IV et la XII siècle, París, CTHS, pp. 495-503.

Dierkens, Alain (2003), Les funérailles royales Carolingiennes, en Dierkens, Alain; Marx, Jacques (eds.), La sacralisation du pouvoir. Images et mises en scène, Bruselas, ULB, pp. 45-58.

Domínguez Sánchez, Santiago (2000), Colección del monasterio de Santa María de Carbajal (1093-1461), León, Centro de Estudios "San Isidoro".

Durliat, Marcel (1962), L'Art roman en l'Espagne, París, Braun.

Erlande-Brandenburg, Alain (1975), Le roi est mort. Étude sur les funérailles, les sépultures et les tombeaux des rois de France jusqu'à la fin du XIIIe siècle, París, Société Française d'Archéologie.

Español, Francesca (1996), Massifs occidentaux dans l'architecture romane catalane, "Cahiers de Saint Michel de Cuxà" 27, pp. 57-77.

Esteban, Julián; García Cuetos, Pilar (2007), Alejandro Ferrant y la conservación monumental en España (1929-1939). Castilla y León y la primera zona monumental, Salamanca, Junta de Castilla y León.

Estepa, Carlos (1977), Estructura social de la ciudad de León (siglos XI-XIII), León, Monteleón.

Fernández Conde, F. Javier, Santos, M.C. (1987), La corte asturiana de Pravia. Influencias visigodas en los testimonios arqueológicos, "BIDEA" 122, pp. 315-344.

Fernández Conde, F. Javier; Alonso, Gabino A.; Argüello, José Jorge (1991), Enterramientos medievales en la iglesia de Santianes de Pravia, "Asturiensia medievalia" 6, pp. 11-38. 
Fernández del Pozo, José María (1999), Alfonso V (999-1028). Vermudo III (1028-1037), Burgos, La Olmeda.

Fernández Vallina, Emiliano (1978), Sampiro y el llamado Silense, "Helmantica" 29, p. 51-60.

Fernández Vallina, Emiliano (1995), El obispo Pelayo de Oviedo: su vida y su obra, en Liber Testamentorum Ecclesiae Ovetensis, Barcelona, Moleiro, pp. 341-347.

Flores, Juan J. (1990), La liturgia de la dedicación de iglesias según el manuscrito de Silos, en El Románico en Silos, Burgos, Abadía de Silos, pp. 69-80.

Flórez, Henrique (1771), España Sagrada, Madrid, Pedro Marín, t. XXVI.

Floriano, Pedro (1981), Colección diplomática del monasterio de Villanueva de Oscos. Primera serie (1136-1200), "Boletín del Real Instituto de Estudios Asturianos" 35/102, pp. 127-190.

Gago, Elías; Díaz Jiménez, Juan E. (1911), Autenticidad de los restos mortales de Alfonso VI y sus cuatro mujeres: Inés, Constanza, Zayda y Berta, "Boletín de la Real Academia de la Historia" 58, pp. 40-55.

Gambra, Andrés (1997), Alfonso VI. Cancillería, Curia e Imperio, León, Monteleón.

García Calles, Luisa (1972), Doña Sancha, hermana del emperador, León, CSIC. García de Castro, César (1995), Arqueología cristiana de la Alta Edad Media en Asturias, Oviedo, Real Instituto de Estudios Asturianos.

García de Castro, César (1997), Las estructuras occidentales en la arquitectura altomedieval asturiana", en De Boe, Guy; Verhaeghe, Frans (eds.), Religion and Belief in Medieval Europe, Zellik, Instituut voor het Archeologisch Patrimonium, pp. 159-170.

García de Castro, César (1999), Las primeras fundaciones, en Caso, Francisco de; Cuenca, Cosme; García de Castro, César, La Catedral de Oviedo. Historia y restauración, Oviedo, Nóbel, vol. I, pp. 21-73.

García de Castro, César; Ríos, Sergio (2004), Exploraciones Arqueológicas en la Cámara Santa y su entorno inmediato, en La restauración de la torre y el claustro de la catedral de Oviedo, Hevia, J. (coord.), Oviedo, Nóbel, pp. 252-283.

Garrido, José M. (1983), Documentación de la Catedral de Burgos (8041183), Burgos, Garrido.

Gil, Juan; Moralejo, J. Luis; Ruiz de la Peña, Ignacio (1985), Crónicas asturianas, Oviedo, Universidad.

Gómez-Moreno, Manuel (1919), Iglesias mozárabes. Arte español de los siglos IX al XI, Madrid, Centro de Estudios Históricos.

Gómez-Moreno, Manuel (1925), Catálogo monumental de la provincia de León, Madrid, Ministerio de Instrucción Pública. 
Gómez-Moreno, Manuel (1934), El arte románico español. Esquema de un libro, Madrid, Centro de Estudios Históricos.

Greci, R. (2007), Palazzi, sedi ecclesiastiche, castelli: ubicazioni, funzioni, interferente, en Quintavalle, Arturo Carlo (ed.), Medioevo: la Chiesa e il Palazzo, Parma, Electa, pp. 116-122.

Gros, Miquel dels S. (1966), El ordo romano-hispánico de Narbona para la consagración de iglesias, "Hispania Sacra", 19, pp. 327-401.

Guiance, Ariel (1998), Los discursos sobre la muerte en la Castilla medieval (s. VII-XV), Valladolid, Junta de Castilla y León.

Gutiérrez Baños, Fernando (1997), Las empresas artísticas de Sancho IV, Valladolid, Junta de Castilla y León.

Henriet, Patrick (2000), Deo votas. L'Infantado et la fonction des infantes dans la Castille et le León des Xe-XIIe siècles, en Henriet, Patrick; Legras, Anne Marie (eds.), Au cloître et dans le monde: Femmes, hommes et sociétés (IXe-XVe siècles), Paris, Université Sorbonne, pp. 189-203.

Henriet, Patrick (2002), Rex, lex, plebs. Les miracles d'Isidore de Séville à León (XIe-XIIIe siècles), en Heinzelmann, Martin; Herbers, Klaus; Bauer, Dieter R. (dirs.), Mirakel im Mittelalter. Konzeptionen Erscheinungsformen Deutungen, Stuttgart, Steiner, pp. 334-350.

Henriet, Patrick (2005a), Mille formis Daemon. Usages et fonctions de la Croix dans l'Hispania des IXe-XIe Siècles, en Deswarte, Thomas; Sénac, Philippe (dirs.), Guerre, pouvoirs et idéologies, dans l'Espagne chrétienne aux alentours de l'an Mil. Actes, Turnhout, Brepols, pp. 163-181.

Henriet, Patrick (2005b), Sanctoral clunisien et sanctoral hispanique au XII siècle, ou de l'ignorance réciproque au syncrétisme: à propos d'un lectionnaire de l'office originaire de Sahagún, en Renard, Étienne (ed.), Scribere sanctorum gesta: recueil d'études d'hagiographie médiévale offert à Guy Philippart, Turnhout, Brepols, pp. 209-259.

Henriet, Patrick (2008), Infantes, infantaticum: remarques introductives, "eSpania" 5, http://e-spania.revues.org/12593 [consulta: 29/01/2012].

Henriet, Patrick (2012), L'Historia Silensis, chronique écrite par un moine de Sahagún. Nouveaux arguments, "e-Spania" 14 [consulta: 9/01/2013].

Herráez, María (coord.) (2000), Esplendor y decadencia de un monasterio medieval. El patrimonio artístico de San Benito de Sahagún, León, Universidad.

Herrero, Marta (1998), Colección diplomática del monasterio de Sahagún (857-1230). III. 1073-1109, León, Monteleón.

Huici, Ambrosio (1913), Crónicas latinas de la Reconquista, Valencia, Hijos de F. Vives. 
Isla, Amancio (2007), Memoria, culto y monarquía hispánica entre los siglos X y XII, Jaén, Universidad.

Isla, Amancio (2010), Regnum et sacerdotium. Doctrinas, ideas y poderes, en Boto, Gerardo (dir.), Reino de León (910-1230), Hombres, mujeres, poderes e ideas, León, Edilesa, pp. 57-77.

Kessler, Herbert (2007), A Gregorian Reform Theory of Art?, en Romano, Serena; Enckell, Julie (eds.), Roma e la Riforma gregoriana. Tradizioni e innovazioni artistiche (XI-XII secolo), Roma, Viella, pp. 25-48.

Klinka, Emmanuelle (2007), L'affirmation d'une nouvelle dynastie, "e-Spania" 3, https://e-spania.revues.org/19260?lang=es [consulta: 10/05/2011].

Klinka, Emmanuelle (2008), Sancie, infante puis reine de León, "e-Spania" 5, http://e-spania.revues.org/index11033.html [consulta: 10/05/2011].

Kruger, Kristina (2006), Fürstengrablegen in Nordspanien: die Panteones früh- und hochmittelalterlicher Kirchen, en Brogásser, B. et al. (eds.), Grabkunst und Sepulkralkultur in Spanien und Portugal/Arte funerario y cultura sepulcral en España y Portugal, Fráncfort - Madrid, Iberoamericana, pp. 33-63.

Libro de Regla o cartulario de la antigua abadía de Santillana del Mar (1912), ed. Eduardo Jusué, Madrid, Junta para ampliación de estudios e investigaciones científicas, Centro de estudios históricos.

Linage, Antonio (1999), Tres cuartos de siglo de monacato en el Reino de León: 1050-1125, en López Alsina, Fernando (coord.), El Papado, la iglesia leonesa y la basílica de Santiago a finales del siglo XI: el traslado de la Sede Episcopal de Iria a Compostela en 1095, Santiago de Compostela, Consorcio, pp. 43-70.

Linehan, Peter (1994), León, ciudad regia, y sus obispos en los siglos X-XIII, en El reino de León en la Alta Edad Media VI, León, Monteleón, pp. 409-457.

Llamazares, Julio (1924), Vida y milagros del glorioso San Isidoro, arzobispo de Sevilla y patrón del reino de León, León, Católica.

López Morán, Enriqueta, (2009), Alfonso VI y sus mujeres: ubicación de los restos, Sahagún, Monasterio de las Benedictinas.

López Quiroga, Jorge, Martínez Tejera, Artemio (2009), De corporibus defunctorum: lectura e interpretación histórico-arqueológica del canon XVIII del primer concilio de Braga (a. 561) y su repercusión en la arquitectura hispana de la Antigüedad Tardía, en López, Jorge; Martínez, Artemio (coords.), Morir en el mediterráneo medieval, Oxford, Archaeopress, pp. 153-184.

Lucas de Tuy (1926), Chronicon Mundi. Ab origine mundi usque ad eram MCCLXXIV; Crónica de España, ed. J. Puyol, Madrid, Real Academia de la Historia. 
Lucae Tudensis (2003), Chronicon Mundi, ed. E. Falque, Turnhout, Brepols. Mansilla, Demetrio (1944), La curia romana y el reino de Castilla en un momento decisivo de su historia, 1061-1085, Burgos, Seminario Metropolitano.

Mansilla, Demetrio (1971), Catálogo documental del Archivo Catedral de Burgos (804-1415), Madrid - Barcelona, CSIC (Monumenta Hispaniae Sacra. Subsidia; 2).

Martin, Georges (2008), Le testament d'Elvire (Tábara, 1099), “e-Spania” 5, http://e-spania.revues.org/12303 [consulta: 22/12/2013].

Martin, Georges (2009), Hilando un reino. Alfonso VI y las mujeres, "e-Spania", 10, http://halshs.archives-ouvertes.fr/docs/00/37/68/18/PDF/ HILANDO_UN_REINADO.pdf [consulta: 15/07/2013].

Martin, Therese (2005a), De gran prudencia, graciosa habla y elocuencia $a$ mujer de poco juicio y ruin opinión: recuperando la historia perdida de la reina Urraca (1109-1126), "Compostellanum" 50, pp. 551-578.

Martin, Therese (2005b), The Art of a Reigning Queen as Dynastic Propaganda in Twelfth-Century Spain, "Speculum" 80, pp. 1134-1171.

Martin, Therese (2006), Queen as King. Politics and Architectural Propaganda in Twelfth Century Spain, Leiden, Brill.

Martin, Therese (2008), Hacia una clarificación del infantazgo en tiempos de la reina Urraca y su hija la infanta Sancha (ca. 1107-1159), "e-Spania" 5, http://e-spania.revues.org/ [consulta 22/11/2012].

Martínez Tejera, Artemio (1993a), De nuevo sobre áreas ceremoniales y espacios arquitectónicos intermedios en los edificios hispanos (ss. IV-X): atrio y pórtico, "Boletín de Arqueología Medieval" 7, pp. 163-215.

Martínez Tejera, Artemio (1993b), El contraábside en la arquitectura de repoblación: el caso castellano-leonés, en Repoblación y reconquista. Actas del III Curso de Cultura medieval, Aguilar de Campoo, Fundación Santa María la Real, pp. 149-161.

Martínez Tejera, Artemio (1996), Dedicaciones, consagraciones y monumenta consecrationes (ss.VI-XII): testimonios epigráficos altomedievales en los antiguos reinos de Asturias y León, "Brigecio" 6, pp. 77-102.

Martínez Tejera, Artemio (2002), Cenobios leoneses altomedievales ante la europeización: San Pedro y San Pablo de Montes, Santiago y San Martín de Peñalba y San Miguel de Escalada, "Hispania Sacra" 54,pp. 87-108.

Martínez Tejera, Artemio (2004), Arquitectura monástica en tiempos de San Genadio (;865? 935/937): San Miguel de Escalada y Santiago de Peñalba (prov. de León), Madrid, Universidad Autónoma (tesis doctoral, inédita).

Martínez Tejera, Artemio (2008), El Pórtico románico: origen y funcionalidad de un espacio arquitectónico intermedio de la edilicia medieval 
hispana (atrium/porticus/vestibulum), en Espacios y estructuras singulares del edificio románico, Aguilar de Campoo, Fundación Santa María la Real, pp. 191-227.

Martínez Tejera,Artemio (2010), La ecclesia de Peñalba de Santiago (El Bierzo, León): arquitectura de fusión en el reino de León (siglo X), Madrid, Asociación para el Estudio y Difusión del Arte Tardoantiguo y Medieval.

Martínez, Martín (ed.) (1997), Cartulario de Santa María de Carracedo 992-1500, Ponferrada, Instituto de Estudios Bercianos.

Mattoso, José, (1993), A morte dos reis na cronística pré-afonsina, "Estudos medievais" 10, pp. 79-96.

Menéndez Pidal, Luis (1980), La basílica de Santianes de Pravia (Oviedo), en Actas del Simposio para el estudio de los códices del Comentario al Apocalipsis de Beato de Liébana, Madrid, Joyas bibliográficas, vol. 3, pp. 279-297.

Menjot, Denis (1998), Un chrétien qui meurt toujours: les funérailles Royales en Castille à la fin du Moyen Age, en Núñez, Manuel; Portela, Ermelindo (eds.), La idea y el sentimiento de la muerte en la historia y el arte de la Edad Media, Santiago de Compostela, Universidade, vol. I, pp. 127-138.

Miguel, Fernando (1996), Monasterios leoneses en la Edad Media: los casos de Palat de Rey y Carracedo, en Arqueoleón. Historia de León a través de la Arqueología, León, Junta de Castilla y León, pp. 131-162.

Morais, José (2008), La recuperación de la Ecclesiae Primitiva Formae en la escultura del Panteón Real de San Isidoro de León, León, Universidad.

Moralejo, Serafín (1984), La reutilización e influencia de los sarcófagos antiguos en la España medieval, en Andreae, Bernard; Settis, Salvatore (eds.), Colloquio sul reimpiego dei sarcofagi romani nel medioevo, Pisa - Marburg, BPR Publishers, pp. 187-203.

Moralejo, Serafín (1989), Le origini del programma iconografico dei portali nel Romanico spagnolo, en Wiligelmo e Lanfranco nell'Europa romanica, Módena, Panini, pp. 35-51.

Morales, Ambrosio de (1765), Viaje a los reynos de Leon y Galicia y principado de Asturias, ed. Henrique Flórez (ed.), Madrid (ed. facsímil Oviedo, 1977).

O'Callaghan, Joseph (1985), The interpretation of Christian Spain into Europe, en Santiago, Saint-Denis and St. Peter, Nueva York, Fordham.

Pace, Valentino (2007), La Riforma e i suoi programmi figurativi: il caso romano, en Romano, Serena; Enckell Julliard, Julie (eds.), Roma e la Riforma gregoriana. Tradizioni e innovazioni artistiche (XI-XII secolo), Roma, Viella, pp. 49-59. 
Pérez, Maurilio (ed.) (1997), Crónica del Emperador Alfonso VII, León, Universidad.

Pérez de Urbel, Justo (1952), Sampiro, su crónica y la monarquía leonesa del siglo $X$, Madrid, CSIC.

Pérez de Urbel, Justo; González, Atilano (eds.) (1959), Historia Silense, Madrid, CSIC.

Prada, Encina; Vidal, Julio (2007), Arqueo-antropologia del panteón real de San Isidoro de León, en Monarquía y sociedad en el reino de León. De Alfonso III a Alfonso VII, León, Monteleón, pp. 599-688.

Prada, María Encina; Vidal, Julio (2009), La muerte de los reyes de León (siglos X-XI): aspectos históricos, arqueológicos y antropológicos desde el Panteón Real de San Isidro de León, en López, Jorge; Martínez, Armenio (coords.), Morir en el mediterráneo medieval, Oxford, John and Erica Hedges, pp. 239-320.

Puyol Alonso, Julio (1915), El abadengo de Sahagún, Madrid, Minuesa de los Ríos.

Puyol Alonso, Julio (1926), Orígenes del reino de León y de sus instituciones políticas, Madrid, J. Ratis Martín impr.

Quintana Prieto, Augusto (1977), El obispado de Astorga en el siglo XI, León, Cornejo.

Reglero, Carlos (2007), La primera reforma cluniacense de Sahagún, el concilio de Burgos y la crisis de 1080: revisión cronológica y desarrollo, en Fernández Catón, José María (ed.), Monarquía y sociedad en el Reino de León: de Alfonso III a Alfonso VII, León, Monteleón, vol. 2, pp. 689-732.

Reglero, Carlos (2008), Cluny en España. Los prioratos de la provincia y sus redes sociales (1073-ca. 1270), León, Monteleón.

Reilly, Bernard (1989), El reino de León y Castilla bajo Alfonso VI, 10651109, Toledo, Instituto de Estudios Toledanos.

Risco, Manuel (1792), Historia de la ciudad y corte de León y de sus reyes, Madrid, Blas Roman.

Risco, Manuel (1796), España Sagrada, vol. XXXIV, Madrid, Viuda e hijo de Marin.

Robb, David (1945), The capitals of the Panteón de los Reyes, San Isidoro de León, "The Art Bulletin" 27, pp. 165-177.

Rodrigo Jiménez de Rada [Roderici Ximeni de Rada] (1987), Historia de Rebus Hispania sive Historia Gothica, ed. Juan Fernández Valverde, Turnhout, Brepols.

Rodríguez, Justiniano (1972), Ramiro II, rey de León, Madrid, CSIC.

Rucquoi, Adeline (1995), De los reyes que no son taumaturgos: los fundamentos de la realeza en España, "Temas Medievales" 5, pp. 163-186. 
Rucquoi, Adeline (2010), Cluny, el camino francés y la reforma gregoriana, "Medievalismo" 20, pp. 97-122.

Ruiz Asencio, José Manuel (1973), La inclusión del Chronicon de Sampiro en la Historia Silense, "Archivos Leoneses" 54, pp. 279-286.

Ruiz Asencio, José Manuel (1990), Colección documental del archivo de la catedral de León (775-1230). IV (1032-1109), León, Monteleón.

Ruiz de la Peña, Juan Ignacio (2001), La monarquía asturiana, Oviedo, Nóbel.

Salvini, Roberto (1962), La escultura románica en Europa, México, UTEHA.

Sánchez Alonso, B. (ed.) (1924), Crónica del obispo don Pelayo, Madrid, Junta para la ampliación de estudios e investigaciones científicas, Centro de estudios históricos.

Sánchez Candeira, Alfonso (1999), Castilla y León en el siglo XI. Estudio del reinado de Fernando I, ed. Rosa Montero Tejada, Madrid, Real Academia de la Historia.

Sansterre, Jean-Marie (dir.) (2004), L'autorité du passé dans les sociétés médiévales, Roma, École Française.

Schlunk, Helmut (1980), El arte asturiano en torno al 800, en Actas del Simposio para el estudio de los códices del Comentario al Apocalipsis de Beato de Liébana, Madrid, Joyas Bibliográficas, vol. II, pp. 135-162.

Selgas, Francisco de (1890), La primitiva basílica de Santa María del rey Casto de Oviedo y su real panteón, "Boletín de la Real Academia de la Historia" 36, pp. 291-312.

Selgas, Francisco de (1902), La primitiva basílica de Santianes de Pravia y su panteón regio, "Boletín de la Sociedad Española de Excursiones" 10/107, pp. 5-14; 10/108, pp. 28-34; 10/109, pp. 52-57.

Selgas, Francisco de (1908), Monumentos ovetenses del siglo IX, Madrid, Nueva Imprenta San Francisco de Sales.

Senra, José Luis (1997), Aproximación a los espacios litúrgico-funerarios en Castilla y León: pórticos y galileas, "Gesta" 36/2, pp. 122-144.

Senra, José Luis (2002a), Les massifs occidentaux des églises dans les royaumes du nord-ouest de la Péninsule Ibérique, en Sapin, Christian (ed.), Avant-nefs et espaces d'accueil dans l'église entre el IV et la XII siècle, Paris, CTHS, pp. 336-350.

Senra, José Luis (2002b), Ben per está aos reis d'amaren Santa Maria: la capilla de Nuestra Señora en el monasterio de San Salvador de Oña: una iniciativa de Sancho IV el Bravo (1285) en el Marco de un panteón funerario, en Barral, María Dolores; López Vázquez, José Manuel (eds.), Estudios sobre patrimonio artístico: homenaje a la Prof. Dra. $M^{a}$. del Socorro Ortega Romero, Santiago de Compostela, Xunta de Galicia, pp. 141-163. 
Senra, José Luis (2006), Mio Cid es de Bivar e nos los condes de Carrión. Los Banu-Gómez de Carrión a la luz de sus epitafios, "Quintana" 5, pp. 233-267.

Senra, José Luis (2010), En torno a las estructuras occidentales de las iglesias románicas: formulación arquitectónica y funcional de las galileas (ca. 1030-1150), en Espacios y estructuras singulares del edificio románico, Aguilar de Campoo, Fundación Santa María la Real,pp. 121-155.

Serrano, Luciano (1935-1936), El Obispado de Burgos y Castilla primitiva desde el siglo V al XIII, Madrid, [Impr. de E. Maestre].

Sureda, Marc (2008), Els precedents de la catedral de Santa Maria de Girona, Gerona, Universitat de Girona (tesis doctoral).

Sureda, Marc (2009), Architecture autour d'Oliba. Le massif occidental de la cathédrale romane de Gérone, en Le monde d'Oliba. Arts et culture en Catalogne et en Occident (1008-1046), "Cahiers de Saint Michel de Cuxa" 10, pp. 223-238.

Tamayo, Juan (1659), Anamnesis siue Commemorationis sanctorum hispanorum, pontificum, martyrum, confessorum, virginum, viduarum ac sanctarum mulierum, VI, Lyon.

Torres, Margarita (2010), De palacio real a palacio de los Quiñones, condes de Luna, en Palacio Conde Luna. Un reino, un futuro, León, Ayuntamiento, pp. 16-31.

Valdés, Manuel; Cosmen Alonso, María Concepción; Herráez Ortega, María Victoria (1994), Una historia arquitectónica de la catedral de León, León, Santiago García.

Valdés, Manuel (2000), El Panteón real de la Colegiata de San Isidoro de León, en Bango, Isidro (dir.), Maravillas de la España medieval. Tesoro sagrado y monarquía, Madrid, Junta de Castilla y León - Caja España, pp. 73-84.

Viñayo, Antonio (1982), Reinas e Infantas de León, abadesas y monjas del monasterio de San Pelayo y de San Isidoro, en Semana de historia del monacato cántabro-astur-leonés, Oviedo, Monasterio de San Pelayo, pp. 123-135.

Viñayo, Antonio (1995), San Isidoro de León: Panteón de reyes. Albores románicos: arquitectura, escultura, pintura, León, Edilesa.

Walker, Rose (1998), Sancha, Urraca and Elvira: the Virtues and Vices of Spanish Royal Women Dedicated to God, "Reading Medieval Studies" 24, pp. 113-138.

Walker, Rose (2000), The Wall Paintings in the Panteon de los Reyes of Leon: a Cycle of Intercession, "The Art Bulletin" 82, pp. 200-225.

Williams, John (1973), San Isidoro de León. Evidence for a new history, "The Art Bulletin" 55/2, pp. 171-184. 
Williams, John (1995), León. The Iconography of the Capital, en Bisson, Thomas N. (ed.), Cultures of Power. Lordship, Status and Process in Twelfth-Century Europe, Filadelfia, University Pennsylvania, pp. 231-258.

Fecha de recepción del artículo: junio 2013

Fecha de aceptación y versión final: marzo 2014 